\title{
Calcium Regulation in the Protozoan Model, Paramecium tetraurelia
}

\author{
Helmut Plattner \\ Department of Biology, University of Konstanz, P.O. Box 5544, 78457, Konstanz, Germany
}

\section{Keywords}

$\mathrm{Ca}^{2+}$; ciliate; protozoa; signaling; signal

transduction

\section{Correspondence}

H. Plattner, Department of Biology, University of Konstanz, P.O. Box 5544, 78457 Konstanz, Germany

Telephone number: (0)7531 882228;

e mail: helmut.plattner@uni konstanz.de

\begin{abstract}
Early in eukaryotic evolution, the cell has evolved a considerable inventory of proteins engaged in the regulation of intracellular $\mathrm{Ca}^{2+}$ concentrations, not only to avoid toxic effects but beyond that to exploit the signaling capacity of $\mathrm{Ca}^{2+}$ by small changes in local concentration. Among protozoa, the ciliate Paramecium may now be one of the best analyzed models. Ciliary activity and exo- $/$ endocytosis are governed by $\mathrm{Ca}^{2+}$, the latter by $\mathrm{Ca}^{2+}$ mobilization from alveolar sacs and a superimposed store-operated $\mathrm{Ca}^{2+}$-influx. Paramecium cells possess plasma membrane- and endoplasmic reticulum-resident $\mathrm{Ca}^{2+}$-ATPases/ pumps (PMCA, SERCA), a variety of $\mathrm{Ca}^{2+}$ influx channels, including mechanosensitive and voltage-dependent channels in the plasma membrane, furthermore a plethora of $\mathrm{Ca}^{2+}$-release channels (CRC) of the inositol 1,4,5trisphosphate and ryanodine receptor type in different compartments, notably the contractile vacuole complex and the alveolar sacs, as well as in vesicles participating in vesicular trafficking. Additional types of CRC probably also occur but they have not been identified at a molecular level as yet, as is the equivalent of synaptotagmin as a $\mathrm{Ca}^{2+}$ sensor for exocytosis. Among established targets and sensors of $\mathrm{Ca}^{2+}$ in Paramecium are calmodulin, calcineurin, as well as $\mathrm{Ca}^{2+} /$ calmodulin-dependent protein kinases, all with multiple functions. Thus, basic elements of $\mathrm{Ca}^{2+}$ signaling are available for Paramecium.
\end{abstract}

WORK published on $\mathrm{Ca}^{2+}$ in cells is legion, but mostly it has been performed with mammalian cells. Only rather few studies have dealt with free-living (Plattner et al. 2012; Plattner and Klauke 2001) and with parasitic protozoa (Moreno and Docampo 2003). Recently, there has been increasing interest in $\mathrm{Ca}^{2+}$ signaling especially in parasitic protozoa, but this meets many more methodical difficulties than work with free-living species. Another emerging aspect is that $\mathrm{Ca}^{2+}$ regulation and signaling must have been developed early in evolution, probably simultaneously with the formation of intracellular compartments and vesicle trafficking (Cai 2008; Plattner and Verkhratsky 2013). This review aims at elaborating features in common with higher eukaryotes and to pinpoint specific features pertinent to ciliates, based mainly on work with Paramecium. The data discussed are substantiated by localization studies summarized in Table 1.

\section{CAPABILITIES OF $\mathrm{CA}^{2+}$ SIGNALING FROM PARAMECIUM TO MAN}

Corollaries of the control of intracellular $\mathrm{Ca}^{2+}$ and its use for signaling

Already early cells must have struggled with leakage of $\mathrm{Ca}^{2+}$ from the sea water, considering the toxicity of intracellular $\mathrm{Ca}^{2+}$ even at moderate concentrations. Not only can DNA and protein molecules be precipitated but also phosphate ions which had been established as the pivotal aspect of bioenergetics in all cells (Plattner and Verkhratsky 2013). Therefore, cells had to evolve means to keep the concentration of free (dissolved) intracellular $\mathrm{Ca}^{2+}$, $\left[\mathrm{Ca}^{2+}\right]_{i}$, at $\sim 100 \mathrm{nM}$ (Berridge et al. 2003; Clapham 2007), i.e. well below that in the outside medium, $\left[\mathrm{Ca}^{2+}\right]_{0}$, which is usually $\sim 1 \mathrm{mM}$. Due to sequestration into organelles 
Table 1. Distribution of selected proteins relevant for $\mathrm{Ca}^{2+}$ regulation, signaling, and homeostasis in Paramecium

\begin{tabular}{|c|c|c|}
\hline Structure & Molecule & References \\
\hline \multirow[t]{3}{*}{ Plasma membrane, somatic } & PMCA & Wright and van Houten (1990) \\
\hline & $\mathrm{Ca}^{2+} / \mathrm{CaM}$ activated $\mathrm{Me}^{+}$channels & Kung et al. (1992) \\
\hline & Mechanosensitive $\mathrm{Ca}^{2+}$ channels & Eckert and Brehm (1979) \\
\hline \multirow[t]{3}{*}{ Parasomal sacs } & PtCRC V 4 & Ladenburger and Plattner (2011) \\
\hline & Calmodulin & Momayezi et al. (1986) \\
\hline & Calcineurin & Momayezi et al. (2000) \\
\hline \multirow[t]{2}{*}{ Plasma membrane, ciliary } & Voltage dependent $\mathrm{Ca}^{2+}$ channels & Machemer and Ogura (1979) \\
\hline & Guanylate cyclase (G cyclase) & Klumpp et al. (1983) \\
\hline \multirow[t]{6}{*}{ Inside cilia (membrane) } & Calmodulin & Momayezi et al. (1986) \\
\hline & Centrin & Gonda et al. (2007) \\
\hline & Guanylate cyclase ( $\mathrm{Ca}^{2+}$ dependent cGMP formation) & Linder et al. (1999) \\
\hline & cGMP activated protein kinase (PKG) & Ann and Nelson (1995) \\
\hline & CDPK & Kim et al. (2002) \\
\hline & Protein phosphatase 1 (PP1) & Momayezi et al. (1996) \\
\hline Basal bodies & Calmodulin & Momayezi et al. (1986) \\
\hline \multirow[t]{6}{*}{ Alveolar sacs } & Calsequestrin LP & Plattner et al. (1997b) \\
\hline & SERCA & Hauser et al. $(1998,2000)$ \\
\hline & & Plattner et al. (1999) \\
\hline & PtCRC IV 1 (RyR LP) & Ladenburger et al. 2009) \\
\hline & PtCRC V 4 & Ladenburger and Plattner (2011) \\
\hline & Guanylate cyclase & Linder et al. (1999) \\
\hline \multirow[t]{4}{*}{ Endoplasmic reticulum } & Calreticulin LP & Plattner et al. (1997b) \\
\hline & SERCA & Hauser et al. (2000) \\
\hline & PtCRC I 1 (with Ins $P_{3}$ binding domain) & Ladenburger and Plattner (2011) \\
\hline & PtCRC IV 1 (RyR LP) & Ladenburger et al. (2006) \\
\hline \multirow[t]{2}{*}{ Trichocyst docking sites } & Calmodulin & Momayezi et al. (1986) \\
\hline & Calcineurin & Momayezi et al. (2000) \\
\hline Trichocyst matrix & $\mathrm{Ca}^{2+} \mathrm{BPs}$ & Klauke et al. (1998) \\
\hline \multirow[t]{3}{*}{ Infraciliary lattice } & Calmodulin & Momayezi et al. (1986) \\
\hline & Centrin & Beisson et al. (2001) \\
\hline & CDPK & Kim et al. (2002) \\
\hline Terminal cisternae & PtCRC VI 3 & Ladenburger and Plattner (2011) \\
\hline \multirow[t]{2}{*}{ Cytostome } & Calmodulin & Momayezi et al. (1986) \\
\hline & PtCRC VI 3 & Ladenburger and Plattner (2011) \\
\hline \multirow[t]{2}{*}{ Food vacuoles and associated vesicles } & Calmodulin & Momayezi et al. (1986) \\
\hline & PtCRC III 4 & Ladenburger and Plattner (2011) \\
\hline Recycling vesicles from food vacuoles & PtCRC III 4 & Ladenburger and Plattner (2011) \\
\hline Undefined cortical vesicles & PtCRC VI 2 & Ladenburger and Plattner (2011) \\
\hline \multirow[t]{2}{*}{ Contractile vacuole complex smooth spongiome } & PtCRC II 1 (InsP $\left.{ }_{3} R\right)$ & Ladenburger et al. (2006) \\
\hline & PtCRC V 4 & Ladenburger and Plattner (2011) \\
\hline \multirow[t]{3}{*}{ Radial arms (canals) } & Calmodulin & Momayezi et al. (1986) \\
\hline & PtCRC II 1 (InsP $\left.{ }_{3} R\right)$ & Ladenburger et al. (2006) \\
\hline & PtCRC V 4 & Ladenburger and Plattner (2011) \\
\hline \multirow[t]{3}{*}{ Contractile vacuole (bladder) } & Calmodulin & Momayezi et al. (1986) \\
\hline & PtCRC II 1 (InsP $\left.{ }_{3} R\right)$ & Ladenburger et al. (2006) \\
\hline & PtCRC V 4 & Ladenburger and Plattner (2011) \\
\hline \multirow[t]{2}{*}{ Porus } & PtCRC VI 2 & Ladenburger and Plattner (2011) \\
\hline & PtCRC VI 3 & Ladenburger and Plattner (2011 \\
\hline Macronucleus, inside & Calcineurin & Momayezi et al. (2000) \\
\hline Micronucleus (membrane) & PtCRC V 4 & Ladenburger and Plattner (2011) \\
\hline Cleavage furrow (vesicles) & PtCRC V 4 & Ladenburger and Plattner (2011) \\
\hline
\end{tabular}

PtCRC designates $\mathrm{Ca}^{2+}$ release channels related to Ins $\mathrm{P}_{3} \mathrm{Rs}$ and RyRs. CaM calmodulin. Some localizations are based on functional effects and/or results from cell fractionation (e.g. plasma membrane channels, G cyclase, PKG).

and extensive binding of intracellular $\mathrm{Ca}^{2+}$ to highly acidic proteins, called high capacity/low affinity $\mathrm{Ca}^{2+}$-binding proteins, total intracellular $\mathrm{Ca}^{2+}$ concentration (designated [Ca] free and bound calcium) is $\sim 1 \mathrm{mM}$ in the cytosol and between $\sim 0.1$ and $\geq 10 \mathrm{mM}$ in $\mathrm{Ca}^{2+}$ stores. All these approximate values have been discussed in detail in the context of the cortical $\mathrm{Ca}^{2+}$ stores of Paramecium, the alveolar sacs (Hardt and Plattner 2000). Although actual 
values may deviate more or less from these pilot values, these corollaries make $\mathrm{Ca}^{2+}$ very suitable for signaling for the following reasons. (i) Leakage from outside can be controlled by pumps in the plasma membrane (also an old evolutionary heritage) and in membranes of stores which both keep $\left[\mathrm{Ca}^{2+}\right]_{\mathrm{i}}$ low (Berridge et al. 2003; Clapham 2007). (ii) Low $\left[\mathrm{Ca}^{2+}\right]_{i}$ in the resting cell sets a favorable baseline for $\mathrm{Ca}^{2+}$-based signaling events. (iii) Small increases, mostly by one or two orders of magnitude above $\left[\mathrm{Ca}^{2+}\right]_{i}^{\text {rest }}$, provide energetically favorable conditions for $\mathrm{Ca}^{2+}$ as an intracellular second messenger. (iv) Any increases may also reach mitochondria where $\mathrm{Ca}^{2+}$ activates some of the matrix dehydrogenases of the tricarboxylic acid cycle (Tarasov et al. 2012), thus contributing to energy supply for the re-establishment of $\left[\mathrm{Ca}^{2+}\right]_{i}$ homeostasis. In summary, evolution has tamed toxic $\mathrm{Ca}^{2+}$ and even taken advantage of it for signaling purposes.

\section{Molecular effects of $\mathrm{Ca}^{2+}$}

To achieve signal transfer after a stimulus from the outside, the second messenger $\mathrm{Ca}^{2+}$ has to exert some effect on one of the many target and effector molecules. Examples are the low capacity/high affinity $\mathrm{Ca}^{2+}$-binding proteins, for instance, calmodulin, synaptotagmin and, with some regard, centrin. These proteins undergo significant conformational changes when they bind $\mathrm{Ca}^{2+}$. For instance, a $\mathrm{Ca}^{2+} /$ calmodulin complex may bind to effector molecules (some $\mathrm{Ca}^{2+}$-ATPases/pumps, protein phosphatase $2 \mathrm{~B}$ calcineurin, etc.) or the respective $\mathrm{Ca}^{2+}$-binding protein is an effector by itself (protein kinases type $\mathrm{Ca}^{2+}$ dependent protein kinases [CDPK], synaptotagmin, centrin). Most of these molecules are known from Paramecium. Let us consider some examples in more detail.

(i) Calmodulin is well preserved throughout eukaryotes (Kung et al. 1992) and binds $\mathrm{Ca}^{2+}$ in four consecutive EF-hand motifs I IV, i.e. loops of usually $\sim 12$ amino acids, in a hierarchal sequence with decreasing $\mathrm{Ca}^{2+}$ affinity. $\mathrm{Ca}^{2+}$ is weakly bound by coordinative forces, thus allowing easy association and dissociation, i.e. activation and deactivation cycles in rapid sequence. Calmodulin has many sites of action in a cell. For example, maximal activation of the plasma membrane $\mathrm{Ca}^{2+}$ ATPase (PMCA) requires binding of calmodulin to its carboxy-terminal part. Almost all eukaryotes use this pump. Interestingly, the sarcoplasmic/endoplasmic reticulum $\mathrm{Ca}^{2+}$-ATPase (SERCA) is devoid of a calmodulin-binding domain (Palmgren and Nissen 2011). Both these molecules transiently form a phospho-intermediate and, therefore, are called P-type $\mathrm{Ca}^{2+}$-ATPases and both occur in Paramecium (Wright and van Houten 1990; Hauser et al. 1998).

(ii) In metazoans, synaptotagmin is the $\mathrm{Ca}^{2+}$ sensor inducing the fusion of membranes/compartments (Rizo et al. 2006) tethered to each other by SNARE proteins (soluble $\mathrm{N}$-ethylmaleimide sensitive factor [NSF] attachment protein receptors) in conjunction with monomeric GTP-binding proteins (monomeric G-proteins, small GTPases). Synaptotagmin contains two C2-domains, C2A and C2B, each with a $\beta$-barrel motif. From this, a $\mathrm{Ca}^{2+}$-binding loop sticks out which, when activated by $\mathrm{Ca}^{2+}$, can interact with membrane lipids in a way to promote fusion. Isoforms with different $\mathrm{Ca}^{2+}$ binding properties occur (Sugita et al. 2002). In gland cells, for instance, different synaptotagmins are distributed over different kinds of vesicles undergoing trafficking (Becherer et al. 2012). A detailed map of intracellular distribution of SNAREs exists for Paramecium (Plattner 2010), but any equivalent of synaptotagmin is not known from any protozoan.

(iii) Some cytosolic proteins contain not only EF-hand motifs like calmodulin, but in addition acidic stretches with high $\mathrm{Ca}^{2+}$ binding capacity. An example is centrin the molecule enabling some protozoa to rapidly contract, as known from Paramecium.

On this background we may now consider in detail the situation in Paramecium.

\section{$\mathrm{Ca}^{2+}$ extrusion at the cell surface}

At the cell membrane, the PMCA-type $\mathrm{Ca}^{2+}$-ATPase $\left(\mathrm{Ca}^{2+}\right.$ pump) permanently extrudes $\mathrm{Ca}^{2+}$ from the cell. As its activity is accelerated by a $\mathrm{Ca}^{2+} /$ calmodulin complex (see above) increasing $\left[\mathrm{Ca}^{2+}\right]_{i}$ facilitates re-establishment of $\left[\mathrm{Ca}^{2+}\right]_{i}^{\text {rest }}$. As a P-type ATPase, the PMCA is auto-phosphorylated and auto-dephosphorylated with each activity cycle. In the heart muscle sarcolemma, a $\mathrm{Ca}^{2+} / \mathrm{Na}^{+}$antiporter (exchanger) supports this ongoing activity, with sodium being equilibrated by a secondary active transport process. Although claimed also for ciliates (Burlando et al. 1999), such activity could not be convincingly ascertained.

\section{$\mathrm{Ca}^{2+}$ channels in the cell membrane}

The $\mathrm{Ca}^{2+}$ influx channels contained in the cell membrane may be activated by different stimuli. Examples are mechanosensitive channels and voltage-dependent $\mathrm{Ca}^{2+}$ channels. Such channels are known from protozoa up to man, but their molecular and functional properties may greatly vary. For instance, when a Paramecium cell hits its "nose" on an obstacle, this activates mechanosensitive $\mathrm{Ca}^{2+}$-influx channels in the somatic (nonciliary) cell membrane, causing generation of a receptor potential based on $\mathrm{K}^{+}$-efflux and $\mathrm{Ca}^{2+}$-influx. Here, $\mathrm{Ca}^{2+}$ quite unusually serves as a charge carrier. This depolarizing signal activates voltage- (depolarization-) dependent $\mathrm{Ca}^{2+}{ }_{-}$influx channels in the ciliary membranes. Activation means a conformational change in the molecule and concomitantly of its conductivity due to the voltage applied. In consequence, the increase in $\left[\mathrm{Ca}^{2+}\right]$ inside cilia causes a reversal of the ciliary beat (ciliary reversal). These channels are rapidly inactivated by binding of a $\mathrm{Ca}^{2+} /$ calmodulin complex which forms upon $\mathrm{Ca}^{2+}$ influx (Brehm and Eckert 1978). Basically, this feedback mechanism is conserved 
for L-type $\mathrm{Ca}^{2+}$-influx channels up to neuronal cells in our brain (Levitan 1999; Oliveria et al. 2012) a fundamental mechanism underlying our intellectual capabilities. Later on we will see the involvement of calcineurin in this basic response, which, in man, is also pivotal for brain function and the immune response. Thus, evolution has provided essential tools already at the level of Paramecium.

In Paramecium, there are also $\mathrm{Ca}^{2+}$ influx channels sensitive to hyperpolarization (Preston et al. 1992). Their activation causes accelerated forward swimming, as occurs during mechanical stimulation of a Paramecium cell at its rear end. In addition, a Paramecium cell contains $\mathrm{Na}^{+}$ influx and $\mathrm{K}^{+}$efflux channels which are activated by $\mathrm{Ca}^{2+}$ / calmodulin (Kung et al. 1992).

These examples clearly show some basic aspects of the complexity of $\mathrm{Ca}^{2+}$ signaling aiming at a final goal: depending on the stimulus $\mathrm{Ca}^{2+}$ enters at different sites of the cell surface, or it is released from different stores, to exert, directly or indirectly, a local effect (e.g. in cilia, exocytosis sites). This anticipates the general rule that every cell, including Paramecium, must regulate the $\mathrm{Ca}^{2+}$ signal locally at different sites in response to different signals. Figure 1 gives an example what one can see with a fluorochrome during stimulation of trichocyst exocytosis (Klauke and Plattner 1997). Signals are so much restricted that their actual, very local value cannot be demonstrated with a $\mathrm{Ca}^{2+}$ fluorochrome. Comparison with the calibrated values in Fig. 1 shows that the actual $\left[\mathrm{Ca}^{2+}\right]_{i}$ value at an exocytosis site is estimated between 1 and $10 \mu \mathrm{M}$, probably around $\tau \mu \mathrm{M}$, i.e. almost one order of magnitude higher than that derived from calibrated fluorochrome signals due to restricted resolution. This estimation is based on the monitoring exocytosis events after injection of $\mathrm{Ca}^{2+}$ chelators with different $\mathrm{Ca}^{2+}$ affinity (Klauke and
Plattner 1997). When many sites are activated, synchronous trichocyst exocytosis may ensue due to signal spiltover (Plattner 1987; Plattner et al. 1993). The actual duration of the $\mathrm{Ca}^{2+}$ signal during trichocyst exocytosis can be registered only electrophysiologically (Erxleben et al. 1997) by $\mathrm{Ca}^{2+} /$ calmodulin-activated currents (Fig. 2). Signals from all activated sites pile up and $\mathrm{Ca}^{2+}$ can synchronously activate exocytosis. Also subsequent steps up to exocytosis-coupled endocytosis and retrieval of empty membrane "ghosts" are activated by the signal triggered by exocytosis stimulation (Plattner et al. 1997a), as summarized in Fig. 3.

Why locally defined $\left[\mathrm{Ca}^{2+}\right]_{i}$ signals are generally favorable and even required for the cell is discussed below. Beyond this, the wide diversification of plasmalemmal ion channels, including $\mathrm{Ca}^{2+}$ influx channels in Paramecium (Machemer 1988) suggests two aspects: (i) their emergence early in evolution and (ii) in part convergent and in part divergent evolution of precursor molecules. Examples are conservation of voltage sensitivity of some channels and in part aberrant pharmacology of some other channels (Plattner et al. 2009), respectively.

\section{Organelles serving as $\mathrm{Ca}^{2+}$ stores}

In mammalian cells, the endoplasmic reticulum (ER) is a $\mathrm{Ca}^{2+}$ store of paramount importance (as is the sarcoplasmic reticulum [SR] in muscle cells). This also includes the nuclear membrane compartment. The SR of metazoan muscle cells recalls the alveolar sacs of alveolates and these have been identified as cortical $\mathrm{Ca}^{2+}$ stores biochemically (Stelly et al. 1991; Länge et al. 1995) and by electron spectroscopic imaging by Knoll et al. (1993). However, in metazoans endosomes also contain $\mathrm{Ca}^{2+}$, in decreasing
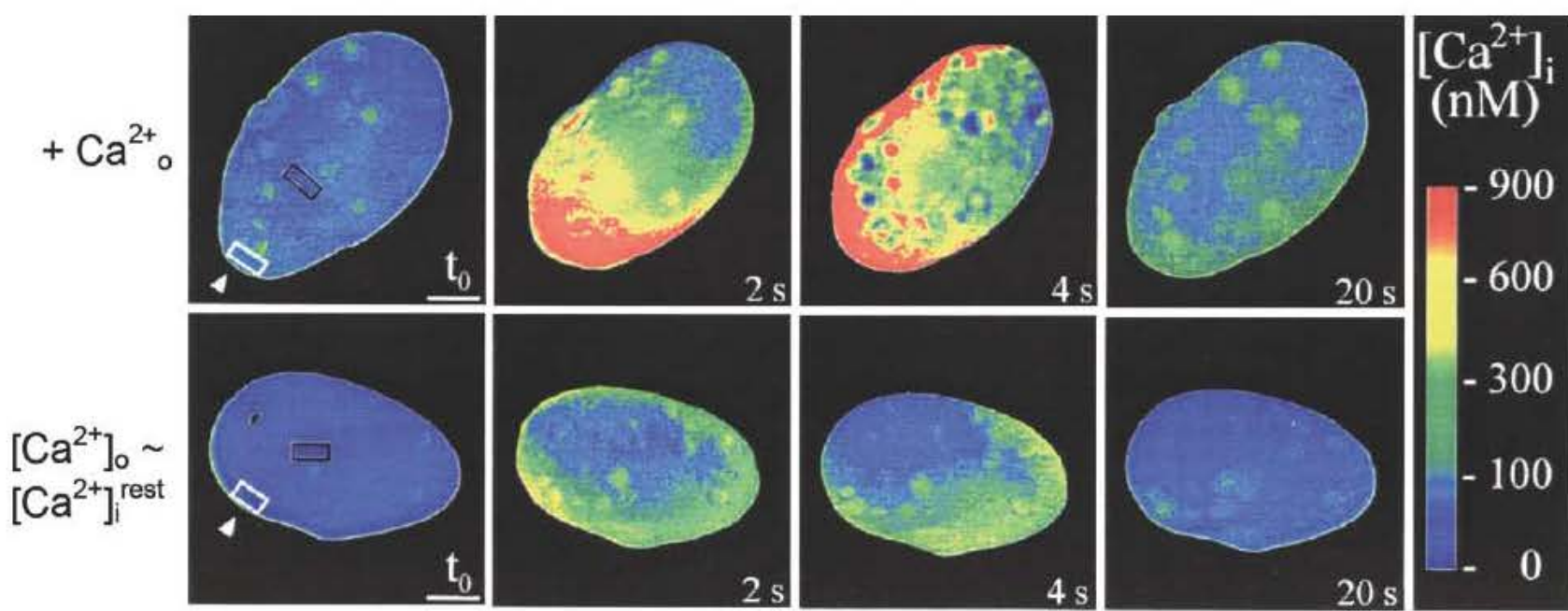

Figure 1 Fluorochrome $f / f_{0}$ ratio imaging of $\mathrm{Ca}^{2+}$ signaling during stimulation of trichocyst exocytosis in Paramecium tetraurelia cells with the RyR agonist caffeine. Strain trichless cells were used to avoid dislocation by trichocyst exocytosis, injected with the fluorochrome Fura Red and stimulated at $\left[\mathrm{Ca}^{2+}\right]_{\circ} \quad 50 \mu \mathrm{M}$ (top) or at $\left[\mathrm{Ca}^{2+}\right]_{0} \sim 30 \mathrm{nM}$ (bottom). Note that the signal is much higher with $\left[\mathrm{Ca}^{2+}\right]_{\circ} \quad 50 \mu \mathrm{M}$ than at low concen tration and signal spreading from the stimulation site (boxed area) already within $2 \mathrm{~s}$. Actual $\left[\mathrm{Ca}^{2+}\right]_{i}$ occurring in the small area where focal mem brane fusion occurs cannot be resolved for reasons indicated in the text. Scale bar $20 \mu \mathrm{m}$. Right column: For $\left[\mathrm{Ca}^{2+}\right]_{i}$ scaling capillaries filled with a medium corresponding the intracellular milieu with Fura Red added were analyzed. From Klauke and Plattner (1998). 

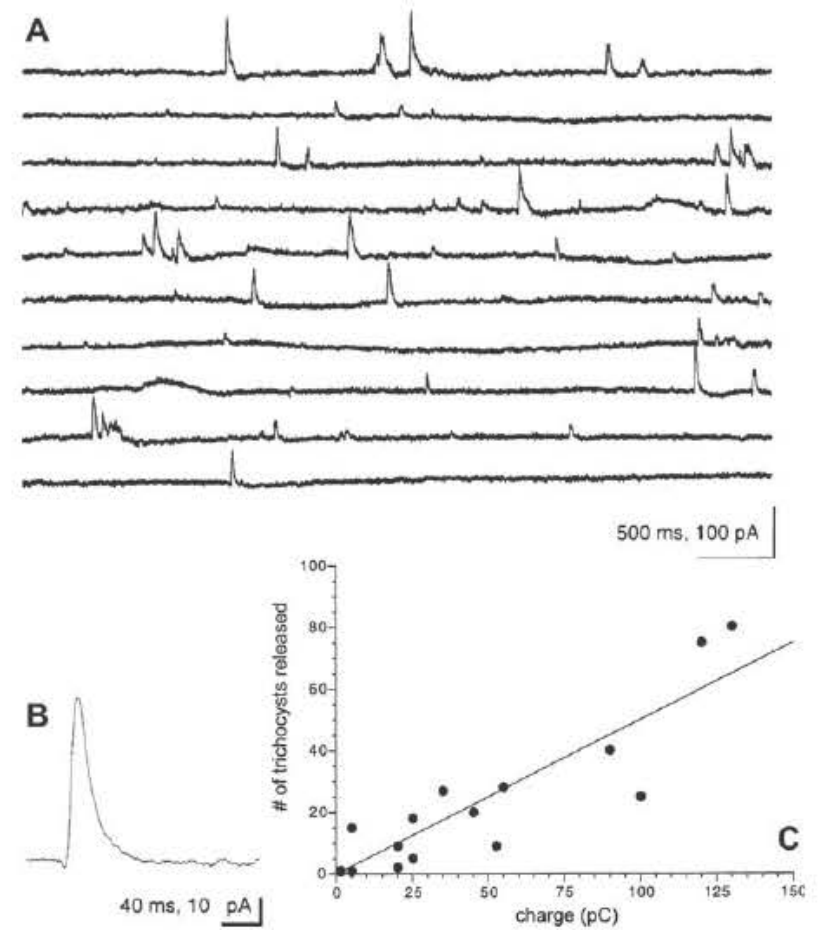

Figure 2 Recording of $\mathrm{Ca}^{2+}$ activated currents by whole cell patch electrophysiological analysis with Paramecium tetraurelia cells. Cells were patched in a pipette to measure electrical current with or with out exocytosis stimulation. Current peaks observed in (A) are acti vated by $\mathrm{Ca}^{2+} /$ calmodulin (as shown separately in the original work) and, thus, can indicate subplasmalemmal $\left[\mathrm{Ca}^{2+}\right]_{i}$ increases in parallel to spontaneous trichocyst exocytosis. The size of the peaks has been correlated with the actual number of exocytosis events observed (C). The minimal peaks in (A) corresponding individual events have been pooled in (B). The resulting average half width of the $\mathrm{Ca}^{2+}$ signal, $21 \mathrm{~ms}$, characterizes the duration of the $\mathrm{Ca}^{2+}$ signal at the cell mem brane. From Erxleben et al. (1997).

concentrations from early to late stages (Luzio et al. 2010), as do lysosomes (Christensen et al. 2002). The requirement of $\mathrm{Ca}^{2+}$ for phagosome-lysosome fusion is also well established (Jaconi et al. 1990). Note that these organelles represent stores of varying luminal $\mathrm{pH}$. To this, one has to add acidocalcisomes (Docampo et al. 2005).

Although these details have not yet been sufficiently analyzed in any protozoan, crystal vacuoles are known specifically from protozoa including Tetrahymena (Coleman et al. 1972) and Paramecium (Grover et al. 1997). In general terms, for the different $\mathrm{Ca}^{2+}$ stores, the mechanisms of $\mathrm{Ca}^{2+}$ sequestration may be different, as are their $\mathrm{Ca}^{2+}$. release channels (CRC). The latter has been verified for Paramecium (Ladenburger and Plattner 2011). For mitochondria, see below.

$\mathrm{Ca}^{2+}$ uptake mechanisms into stores with deviations from the eukaryotic consensus

As the SERCA-type $\mathrm{Ca}^{2+}$ pump is devoid of a calmodulinbinding domain, this molecule is shorter $(\sim 100 \mathrm{kDa})$ than the PMCA ( 120 to $130 \mathrm{kDa}$ ) (Palmgren and Nissen 2011). In Paramecium, the SERCA-type pump occurs in the ER and in the cortical stores, the alveolar sacs (Hauser et al. 1998, 2000; Kissmehl et al. 1998). Figure 4 shows ${ }^{45} \mathrm{Ca}^{2+}$ sequestration by isolated alveolar sacs fractions; equally important is the documentation of release by a $\mathrm{Ca}^{2+}$ ionophore, to exclude adsorption. That $\mathrm{Ca}^{2+}$ uptake is much slower than in mammalian ER/SR has been demonstrated with widely different methods (Mohamed et al. 2003).

Acidocalcisomes, $\mathrm{Ca}^{2+}$ storing vesicles with acidic contents (Docampo et al. 2005), have not yet been identified in Paramecium, although there is some indirect evidence for their existence (Plattner et al. 2012). The enzyme mainly responsible for sequestering $\mathrm{Ca}^{2+}$ into acidocalcisomes of protozoan parasites, such as Toxoplasma and Trypanosoma species, is a PMCA-type $\mathrm{Ca}^{2+}$-ATPase (Docampo et al. 2005). Vacuolar ATPase and pyrophosphatase (PPase) and $\mathrm{Ca}^{2+} / \mathrm{X}^{+}$antiporter systems are also present. Moreover, it has been shown that acidocalcisomes can come into intimate contact with the contractile vacuole in Dictyostelium (Marchesini et al. 2002) and in Trypanosoma (Rohloff and Docampo 2008). Again such knowledge is not available for Paramecium although its contractile vacuole complex is of paramount importance for regulating $\left[\mathrm{Ca}^{2+}\right]_{\mathrm{i}}$ homeostasis (Stock et al. 2002; Plattner et al. 2012; Schönemann et al. 2013). Here, localization studies (Wright and van Houten 1990) did not aim at showing $\mathrm{Ca}^{2+}$-ATPase in the contractile vacuole complex and cilia were also negative. The latter contrasts with recent work in which the validity of antibodies previously used has been questioned (Yano et al. 2013). Therefore, it may well be possible that the contractile vacuole complex of Paramecium would also contain a PMCA-type $\mathrm{Ca}^{2+}$-ATPase, as has been published also for Dictyostelium (Marchesini et al. 2002; Moniakis et al. 1999). In summary, one may expect for the contractile vacuole complex of Paramecium not only the occurrence of a $\mathrm{Ca}^{2+} / \mathrm{H}^{+}$antiporter, but also the occurrence of a PMCA-pump. Nevertheless, in Paramecium much of the $\mathrm{Ca}^{2+}$ handling is based on a primary active transport of $\mathrm{H}^{+}$by a $\mathrm{H}^{+}$-ATPase (proton pump, V- [vesicular] type ATPase without formation of a phospho-intermediate), as described by Plattner et al. (2012) and below.

\section{$\mathrm{Ca}^{2+}$ in bound form in intracellular stores again with deviations among eukaryotes}

As [Ca] in stores can amount from sub-millimolar to tens of millimolar (Plattner et al. 2012), $\mathrm{Ca}^{2+}$ must be osmotically inactivated by binding to high capacity/low affinity $\mathrm{Ca}^{2+}$-binding proteins. In the mammalian ER, this is mainly calreticulin and in the SR calsequestrin, respectively.

The contents of some mammalian secretory organelles bind $\mathrm{Ca}^{2+}$ with high potency. This holds, e.g. for chromaffin granules of the adrenal medulla, where [Ca] may amount to $40 \mathrm{mM}$. By most authors, these organelles are considered not to be crucial for $\mathrm{Ca}^{2+}$ signaling (Becherer et al. 2012). Also the significance of their endowment with InsP $\mathrm{P}_{3} \mathrm{Rs}$ interacting with chromogranin proteins in the 


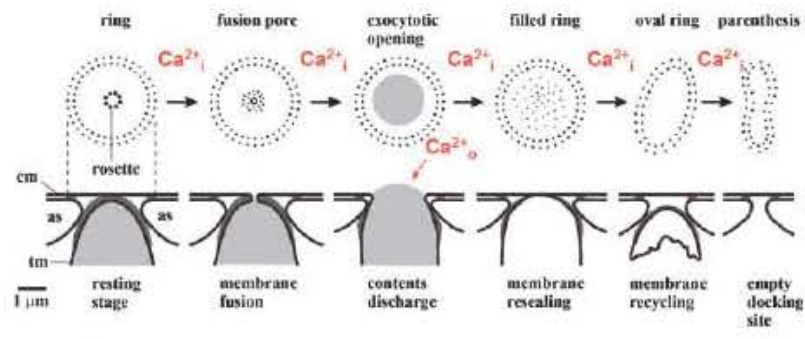

Figure 3 Sequence of events during AED stimulated trichocyst exo cytosis and subsequent membrane resealing in Paramecium tetraur elia. The top row indicates the freeze fracture appearance (ring shaped circumference and a central rosette indicating exocytosis com petence) of exocytosis sites (Plattner et al. 1997a), the bottom row shows the appearance in ultrathin sections. Note progression from ring shape to openings and oval resealing stages during exo endocyto sis coupling, as well as decay of rosette particles during formation of the fusion pore. Also note the stimulating effect of the availability of $\mathrm{Ca}^{2+}$ in the medium lanalyzed separately in experiments with variable $\left[\mathrm{Ca}^{2+}\right]_{\text {o, }}$ Plattner et al. 1997a), not only for progression of all stages but also for the decondensation (explosive stretching) of the tricho cyst contents, i.e. the paracrystalline matrix (Bilinski et al. 1981). as alveolar sacs, $\mathrm{cm}$ cell membrane, tm trichocyst membrane. From Plattner and Hentschel (2006)

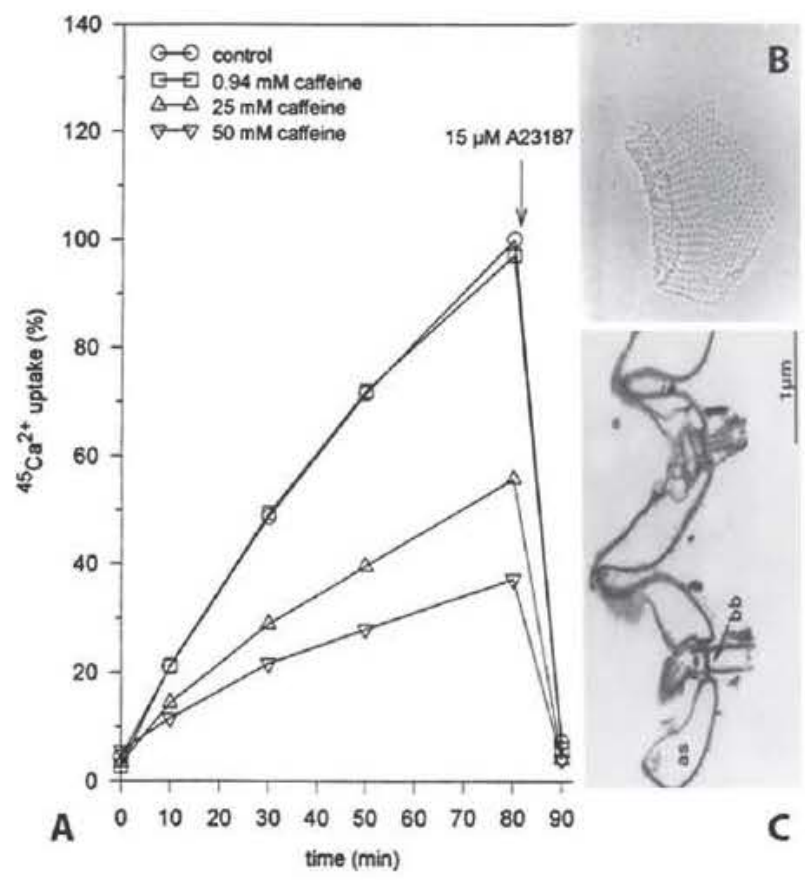

Figure $4{ }^{45} \mathrm{Ca}^{2+}$ sequestration by alveolar sacs isolated from Parame cium tetraurelia cells. The pumping kinetics (A) of isolated alveolar sacs (as) seen in the light (B) and electron microscope (C, with intermittent basal bodies [bb]) are unexpectedly slow. $\mathrm{Ca}^{2+}$ uptake is inhibited by caffeine and complete release is achieved by the $\mathrm{Ca}^{2+}$ ionophore A23187. (A) is from Länge et al. (1996).

secretory contents (Yoo et al. 2010) has not been scrutinized as yet. The opposite is true for Paramecium trichocysts whose mature matrix proteins are devoid of any recognizable $\mathrm{Ca}^{2+}$ content and, moreover, rapidly decondense in contact with extracellular $\mathrm{Ca}^{2+}$ once an exocytic opening has been formed (Bilinski et al. 1981; Hardt and Plattner 2000; Klauke et al. 1998).

\section{Intracellular $\mathrm{Ca}^{2+}$-release channels and second messenger activation}

In higher eukaryotes, the classical activator of $\mathrm{Ca}^{2+}$ from the ER is inositol 1,4,5-trisphosphate $\left(\operatorname{lns}_{3}\right)$ which, upon stimulation, is formed from phosphatidyl inositol 4,5-bisphosphate $\left(\mathrm{Plns}_{2}\right)$ by phospholipase $\mathrm{C}(\mathrm{PLC})$ activity (Berridge et al. 2003; Clapham 2007). Only more recently have PLC enzymes with the potential of $\operatorname{InsP}_{3}$ formation been detected in Toxoplasma gondii (Fang et al. 2006), in Paramecium (Klöppel et al. 2009) and Tetrahymena (Leondaritis et al. 2011; Leondaritis and Galanopoulou 2011). Depending on the system, release of $\mathrm{Ca}^{2+}$ from the ER can also be initiated by activation of ryanodine receptors. Most likely, the physiological equivalent of the plant toxin ryanodine is cyclic adenosine diphosphoribose (CADPR) produced from nicotine amide dinucleotide phosphate $\left(\mathrm{NADP}^{+}\right)$by the enzyme, CD38 (Lee 2012). From the same substrate, the enzyme can also produce nicotinic acid-adenine dinucleotidephosphate (NAADP). NAADP is assumed to activate TwoPore-Channels (TPC; Galione et al. 2009; Lee 2012). Most recently, there is some discussion about this assignment since Wang et al. (2012) found with mammalian endolysosomes that TPCs are $\mathrm{Na}^{+}$-channels rather than $\mathrm{Ca}^{2+}$ channels and that they are activated by phosphoinositides, rather than by NAADP. However, this in turn has been challenged in a most recent report (Churamani et al. 2013). This controversy now needs clarification.

In higher eukaryotes, Ins $\mathrm{P}_{3}$ Rs and RyRs can coexist not only in different organelles of a cell but also within one organelle, such as the ER (McCarron and Olson 2008; Solovyova and Verkhratsky 2003). As will be discussed below, we have InsP $P_{3} R s$ and RyRs or RyR-like proteins in Paramecium. Here, different CRCs can also coexist in the membrane of one specific pool (Ladenburger and Plattner 2011).

Generally, acidic stores are considered the targets of NAADP, from endosomes to lysosomes (Patel and Do campo 2010). Remarkably TPCs are reportedly absent from acidocalcisomes of protozoa (Patel and Muallem 2011). In pilot experiments we saw in Paramecium cells, upon microinjection of CADPR or of NAADP, a physiological reaction indicative of a $\mathrm{Ca}^{2+}$ increase (Plattner et al. 2012). The respective receptor molecule behind remains unexplored. Similarly, any role of members of the superfamily of Transient-Potential-Receptor-Channels (TRPC) which in higher eukaryotes occur either in the plasmalemma or/and in intracellular store membranes (Patel and Docampo 2009) is unknown in ciliates. Sequences of such channels occur in the Paramecium database (Plattner et al. 2012), but any details remain to be elucidated in ciliates. For mitochondria, see below. 


\section{Cooperation between $\mathrm{Ca}^{2+}$ influx and release from cortical stores}

How can an extracellular signal activate an intracellular $\mathrm{Ca}^{2+}$ pool? One way is diffusion of a second messenger (InsP $P_{3}$, cADPR, NAADP) capable of activating $\mathrm{Ca}^{2+}$ release from specific pools. However, there may occur a tight structural and functional coupling of one of the classical pools, i.e. the ER or the SR, specifically its terminal cisternae, with the cell membrane.

The $\mathrm{Ca}^{2+}$ signal generated by the mobilization of ER stores may be enforced by a superimposed $\mathrm{Ca}^{2+}$ influx from the extracellular space (store-operated $\mathrm{Ca}^{2+}$ influx [entry], SOC[E], also called capacitative $\mathrm{Ca}^{2+}$-influx). By timed stimulation, combined with quenched-flow/fast freezing (Knoll et al. 1991a) and energy-dispersive X-ray (EDX) microanalysis in the electron microscope (EM), this has been shown to occur in Paramecium (Hardt and Plattner 1999, 2000); see Fig. 5. Its alveolar sacs are structurally tightly coupled to the cell membrane, thus closely resembling terminal cisternae of the SR. These analyses have been conducted with aminoethyldextrane (AED), a potent secretagogue in Paramecium, at higher $\left[\mathrm{Ca}^{2+}\right]_{0}$ (Plattner et al. 1984, 1985) or in the presence of $\left[\mathrm{Ca}^{2+}\right]_{0}$ $\sim 30 \mathrm{nM}$, i.e. slightly below $\left[\mathrm{Ca}^{2+}\right]_{i}^{\text {rest }}$ (Hardt and Plattner 2000), to avoid superposition by $\mathrm{Ca}^{2+}$ influx. That the latter occurs has been shown separately, e.g. by rapidly substituting $\mathrm{Sr}^{2+}$ for $\mathrm{Ca}^{2+}$. These substitution experiments have definitely shown that $\mathrm{Ca}^{2+}$ release from alveolar sacs is immediately superimposed by $\mathrm{Ca}^{2+}$ influx (exploiting the widely different energy lines of $\mathrm{Sr}^{2+}$ and $\mathrm{Ca}^{2+}$ in EDX) (Hardt and Plattner 1999, 2000). Thus, the storage compartment is refilled while being emptied. Rarely such observations, based on other methodologies, have been reported for mammalian cells, e.g. immuno- and skeletal muscle cells (Narayanan et al. 2003). Also fluorochrome analysis at different $\left[\mathrm{Ca}^{2+}\right]_{0}$ reveals an endogenous and a superimposed exogenous $\mathrm{Ca}^{2+}$ component during trichocyst exocytosis (Klauke and Plattner 1997); see Fig. 1. Finally, genetic elimination of the influx component also allows for $\mathrm{Ca}^{2+}$ mobilization from alveolar sacs, as documented also by EDX (Mohamed et al. 2002). Nevertheless, for a rapid exocytotic response and subsequent exoendocytosis coupling, sufficient $\mathrm{Ca}^{2+}$ in the outside medium, $\left[\mathrm{Ca}^{2+}\right]_{0}$, is important to drive the SOC mechanism, from exocytotic membrane fusion to contents release and detachment of empty vesicles ("ghosts") (Plattner et al. 1997a). With $\left[\mathrm{Ca}^{2+}\right]_{0}<\left[\mathrm{Ca}^{2+}\right]_{i}^{\text {rest }}$, exocytosis stimulation with $A E D$ results only in a small number of exocytosis events. Efficiency increases from $\left[\mathrm{Ca}^{2+}\right]_{0}>0.3 \mu \mathrm{M}$ on, i.e. close to the value estimated for $\left[\mathrm{Ca}^{2+}\right]_{i}$ during activation.

In skeletal muscle cells, the SR is coupled to the sarcolemma by close interaction of voltage-dependent $\mathrm{Ca}^{2+}$ influx channels with the ryanodine receptor-type CRC, i.e. by conformational coupling. Whether the same coupling mechanism applies to the SOC found in Paramecium is not known although it is striking how alveolar sacs are intimately attached to the cell membrane, with the CRCs facing the cell membrane (Fig. 3). In heart muscle cells, $\mathrm{Ca}^{2+}$ release from the SR is activated differently, namely by a $\mathrm{Ca}^{2+}$ influx through plasmalemal voltage-dependent $\mathrm{Ca}^{2+}$ channels in the course of depolarization events accompanying each heart beat (Mackrill 1999). Here, a $\mathrm{Ca}^{2+}$-induced $\mathrm{Ca}^{2+}$ release (CICR) represents the opposite to the SOC mechanism occurring in skeletal muscle. No CICR is known from ciliates.

\section{Immobile $\mathrm{Ca}^{2+}$ buffers cytosolic high capacity/low affinity $\mathrm{Ca}^{2+}$-binding proteins}

Such proteins are not $\mathrm{Ca}^{2+}$ sensor proteins, i.e. they do not directly contribute to signaling. By rapid binding of $\mathrm{Ca}^{2+}$, they serve as a sink of $\mathrm{Ca}^{2+}$ for inactivation. The centrin molecule, including Paramecium centrin, has such properties. In Paramecium, centrin is concentrated in the infraciliary lattice which contracts in response to increased $\left[\mathrm{Ca}^{2+}\right]$ (Beisson et al. 2001). Centrin can in part act as a signaling molecule by virtue of its EF-hand motifs but due to numerous acidic regions with considerable $\mathrm{Ca}^{2+}$ binding capacity in its linear part, centrin is also a high capacity/low affinity $\mathrm{Ca}^{2+}$-binding protein (Gogendeau et al. 2008; Kim et al. 2002). The activity of the infraciliary lattice centrin as a $\mathrm{Ca}^{2+}$ sink has been shown experimentally by knockout experiments (Sehring et al. 2009).

\section{How can a $\mathrm{Ca}^{2+}$ signal become locally restricted and why is local $\left[\mathrm{Ca}^{2+}\right]$ important?}

Close to the mouth of a $\mathrm{Ca}^{2+}$ influx or a $\mathrm{CRC}$, $\left[\mathrm{Ca}^{2+}\right]$ will be highest and most channels are rapidly inactivated. The following mechanisms are important. (i) $\mathrm{Ca}^{2+}$ becomes diluted with distance by a square function. (ii) It is inactivated by binding to $\mathrm{Ca}^{2+}$-binding proteins depending on their binding and time constant, and (iii) by sequestration into storage organelles and/or extrusion from the cell. (iv) Furthermore, the physiological effects of $\mathrm{Ca}^{2+}$ follow a superlinear function of the actual local concentration (Neher 2012). All this entails two major aspects. On the one hand, all these mechanisms serve to restrict the signal and, thus, avoid spreading to irrelevant regions or to reach toxic levels. On the other hand, this requires precise positioning of channels in the cell. If this is provided, the rise of $\left[\mathrm{Ca}^{2+}\right]$ and the reaction to it can remain limited to a small area. For instance, in adrenal medullary chromaffin cells only those granules that are docked close enough to $\mathrm{Ca}^{2+}$ influx channels may be more readily released upon stimulation (Becherer et al. 2003). As far as Paramecium is concerned, this cell has an intriguing spatial arrangement of sites of $\mathrm{Ca}^{2+}$ activation and cell dynamics. The manifold $\mathrm{Ca}^{2+}$ influx and release channels in these cells appear tailor-made for the respective local functions (see below). Otherwise such precision is more broadly known from nerve terminals and neuromuscular junctions. 

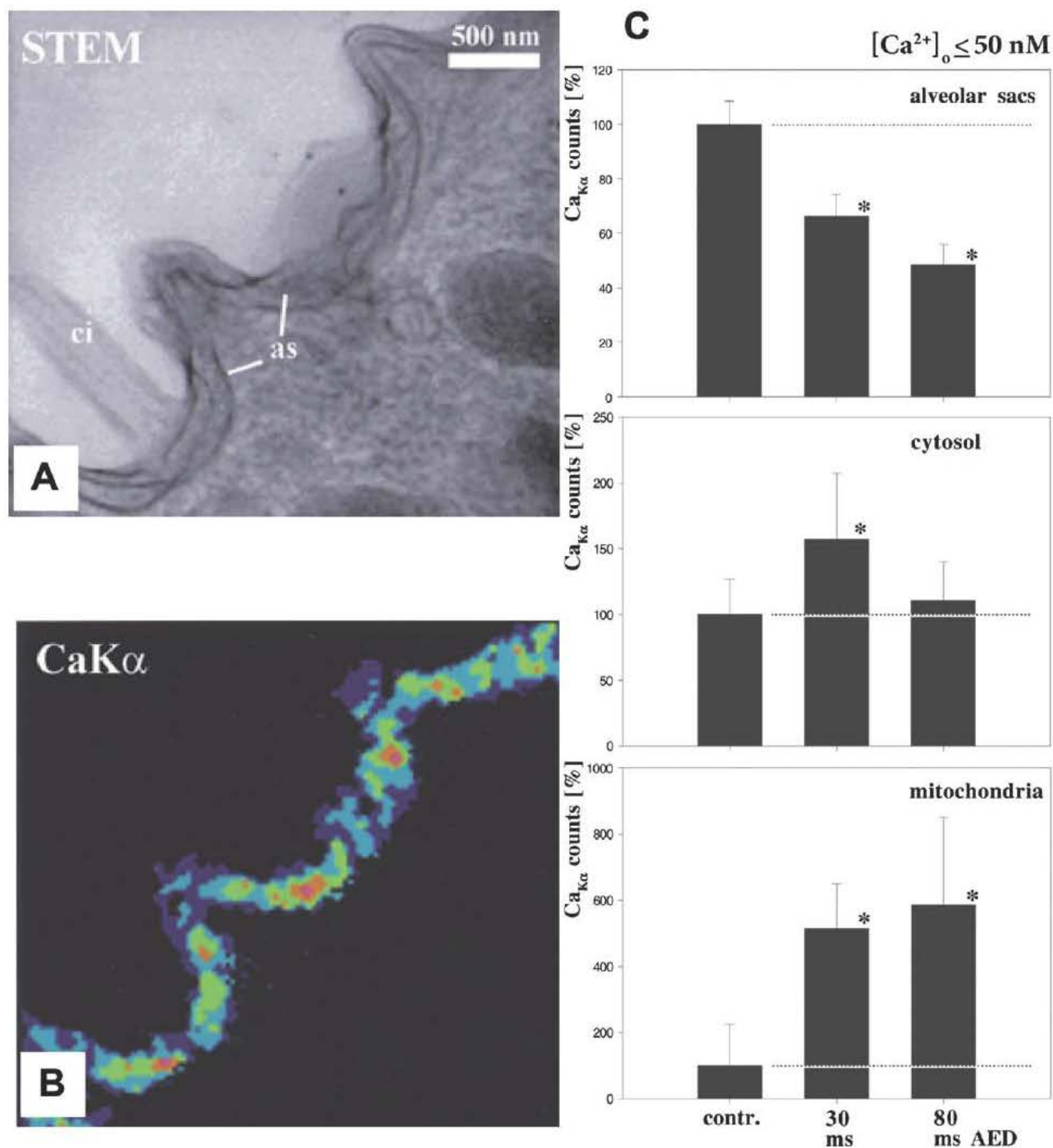

Figure 5 EDX analysis of [Ca] and $\mathrm{Ca}^{2+}$ mobilization and redistribution during trichocyst exocytosis in Paramecium tetraurelia cells stimulated with AED. (A) is a scanning transmission electron micrograph (STEM) obtained from a $0.5 \mu \mathrm{m}$ thick semithin section, as required for EDX. In (B) cal cium is visualized in the same area as in (A) by its specific X ray energy line of $3.691 \mathrm{keV}$, measured in a window from 3.57 to $3.83 \mathrm{keV}$, in a non stimulated cell. As the section plane is not always strictly perpendicular to alveolar sacs and also for theoretical reasons (Hardt and Plattner 1999) the false color $\mathrm{Ca}$ signal appears broader than the underlying structure. (C) presents changes in [Ca] in the compartments indicated, each normal ized to $100 \%$ for the unstimulated state $\left(-40 \mathrm{mM}\right.$ in the sacs, Hardt and Plattner 1999), under conditions precluding $\mathrm{Ca}^{2+}$ influx from outside $\left(\left[\mathrm{Ca}^{2+}\right]_{0} 50 \mathrm{nM}\right.$, i.e. close to $\left[\mathrm{Ca}^{2+}\right]_{i}^{\text {rest }}$ [Klauke and Plattner 1997). Data in (C) are collected from a number of measurements from different experiments. Note swift decay in the sacs, short transient increase in the adjacent cytosol and considerable increase in nearby mitochondria; in these areas, basal [Ca] cannot be imaged in (B) before stimulation due to restricted sensitivity of EDX imaging. Bars standard error of the mean; asterisks indicate statistically significant difference from the respective control. From Hardt and Plattner (2000). 


\section{FOCUSING STILL MORE ON DETAILS SPECIFIC FOR PARAMECIUM}

\section{$\mathrm{Ca}^{2+}$ leakage and $\left[\mathrm{Ca}^{2+}\right]_{\mathrm{i}}$ homeostasis}

Normally Paramecium is cultured in media with $\left[\mathrm{Ca}^{2+}\right]_{\circ} 0.11 \mathrm{mM}$. Ca ${ }^{2+}$ fluxes in nonactivated cells have revealed an unexpectedly high leakage rate (Browning and Nelson 1976; Kerboeuf and Cohen 1990) which must be permanently counteracted. This is achieved in several ways. (i) The cell membrane is endowed with a classical PMCA of $\sim 130 \mathrm{kDa}$ (Wright and van Houten 1990) and (ii) the ER as well as the alveolar sacs with a SERCA-type pump (Hauser et al. 1998, 2000). (iii) The contractile vacuole complex proved to dispose of a highly efficient $\mathrm{Ca}^{2+}$ extrusion mechanism. Using miniature $\mathrm{Ca}^{2+}$ selective electrodes, Stock et al. (2002) have measured a high $\left[\mathrm{Ca}^{2+}\right]$ in the fluid of the contractile vacuole complex. As there is alledgedly no primary active $\mathrm{Ca} 2^{+}$-transporter (yet see above), but only a $\mathrm{V}$-type $\mathrm{H}^{+}$-ATPase present in the organelle membranes (Fok et al. 1995; Wassmer et al. $2005,2006)$, one can assume that a $\Delta \mathrm{H}^{+}$is exploited by $\mathrm{Ca}^{2+} / \mathrm{H}^{+}$exchanger (not identified as yet). This assumption is supported by two facts. On the one hand, no acidic $\mathrm{pH}$ can be detected with a fluorochrome sensitive to protonation (Wassmer et al. 2009), thus indicating ongoing consumption of the $\Delta \mathrm{H}^{+}$. On the other hand, the $\mathrm{H}^{+}$-ATPase inhibitor concanamycin $\mathrm{B}$ extensively inhibits downregulation of $\left[\mathrm{Ca}^{2+}\right]_{i}$ after stimulation of exocytosis (Plattner et al. 2012). By this mechanism, as calculated under defined boundary conditions, a Paramecium cell may be able to extrude all of its $\mathrm{Ca}^{2+}$ within less than $10 \mathrm{~min}$ (Ladenburger et al. 2006). Concomitantly silencing of contractile vacuole complex-resident SNAREs greatly increases the sensitivity to even moderately increased $\left[\mathrm{Ca}^{2+}\right]_{\text {o }}$ (Schönemann et al. 2013). Similarly, inhibition of the organellar $\mathrm{H}^{+}$-ATPase compromises cells in their vitality after increasing $\left[\mathrm{Ca}^{2+}\right]_{0}$ (Sehring et al. 2009).

A sudden change in $\left[\mathrm{Ca}^{2+}\right]_{0}$ causes a rapid transient increase in $\left[\mathrm{Ca}^{2+}\right]_{i}$ without any visible functional consequences, i.e. no ciliary reversal or trichocyst exocytosis occurs. This may be accounted for by a group of the CRCs described below, specifically by PtCRC-V-4. These are greatly concentrated in the parasomal sacs, i.e. clathrincoated pits installed at the basis of cilia (Ladenburger and Plattner 2011). (Consider that several thousand of such sites can be placed on the surface of on Paramecium cell near cilia; Erxleben et al. 1997.) We found that these channels contain a short stretch homologous to an $\operatorname{Ins}_{3}$ binding domain (although actual $\mathrm{InsP}_{3}$ binding has not been shown). These CRCs may account for the not well understood high conductivity channels described in Paramecium by electrophysiologists (Machemer 1988). It thus looks as if these $\mathrm{Ca}^{2+}$-release channels at the cell boundary would allow for $\mathrm{Ca}^{2+}$ "release" from the extremely large extracellular "compartment" into the cytosol. (By comparison, only less than $5 \mathrm{InsP}_{3} \mathrm{R}$-type channel molecules may be localized to the cell membrane of a mammalian gland cell; Dellis et al. 2008.) This type of $\mathrm{Ca}^{2+}$-influx channel may be functionally comparable to a novel type of cation channel with low cation selectivity and high conductivity recently found in hippocampal neurons (Xiong et al. 1997). It may be the alternative to a $\mathrm{Ca}^{2+} /$ polyvalent cation receptor, characterized by five transmembrane domains and coupling to trimeric GTP-binding proteins. This is interesting as in Paramecium neither such receptors nor such G-proteins have been identified conclusively, although evidence for the possible presence of the latter in Paramecium slowly emerges (Lampert et al. 2011) in the literature.

\section{$\mathrm{Ca}^{2+}$ stores}

Paramecium recalls a muscle cell with regard to its major two $\mathrm{Ca}^{2+}$ stores, the $\mathrm{ER}$, and the plasma membrane-associated alveolar sacs. Here, equivalents of both, ER and SR are found, with calreticulin and calsequestrin, respectively. A calreticulin-like protein is localized to the ER and a calsequestrin-like protein to the alveolar sacs (Plattner et al. 1997b). Although this has been established with the best antibodies then available, we could not yet identify these proteins in the Paramecium database. From the distribution of $\mathrm{CRC}$ in a large set of different vesicle types, we conclude that $\mathrm{Ca}^{2+}$ is stored also in the respective organelles all vesicles undergoing trafficking (see below). This is also true for the contractile vacuole complex as it contains calcium (Plattner and Fuchs 1975; Stock et al. 2002) and CRCs (Ladenburger et al. 2006).

$\mathrm{Ca}^{2+}$ can also be stored as a polyphosphate, as is typical of acidocalcisomes occurring from protozoa to mammals (Docampo et al. 2005). Paramecium contains crystal vacuoles with $\mathrm{Ca}, \mathrm{Mg}$-phosphate; according to the X-ray diffraction pattern obtained crystals are identical with struvite. Once more Paramecium looks very "human" as such crystals are one form of kidney stones (Grover et al. 1997). Nothing is known about $\mathrm{Ca}^{2+}$ uptake into, and mobilization from, these organelles.

\section{Ins $\mathrm{P}_{3} \mathrm{Rs}$ and RyR-related $\mathrm{Ca}^{2+}$-release channels in Paramecium}

We found 34 such channels in Paramecium tetraurelia which can be grouped in six subfamilies (Ladenburger and Plattner 2011). They were identified by domain analysis, specifically by the prediction of an $\operatorname{Ins}_{3}$ binding domain, of a ryanodine/lns $\mathrm{P}_{3}$ receptor homology $(\mathrm{RIH})$ domain and particularly of an appropriate channel domain/pore. This domain has to be found in the carboxy-terminal hydrophobic regions where it contains a selectivity filter between the last two transmembrane regions. All $\mathrm{Ca}^{2+}$-release channels of this type found in $P$. tetraurelia, called PtCRC, have six transmembrane domains (see below). Their selectivity filter is largely conserved as Gly-lle-Gly-Asp (GIGD), regardless whether an $\operatorname{Ins}_{3}$ binding domain is present or absent. In higher metazoans, this sequence is restricted to RyRs (Boehning 2010) and the $\operatorname{Ins}_{3} R$ is characterized by GVGD (V valin). Our analysis shows that GIGD is typical of both CRC types in many lower 
eukaryotes (Plattner and Verkhratsky 2013). This and some other features make the PtCRCs prototypes of primeval $\mathrm{Ca}^{2+}$-release channels.

Subfamilies PtCRC-I, PtCRC-II, and PtCRC-III contain an Ins $\mathrm{P}_{3}$-binding domain; a shorter form also occurs in some members of the PtCRC-V subfamily. However, only PtCRC-II has been analyzed in more detail. ${ }^{3} \mathrm{H}-\operatorname{lns} \mathrm{P}_{3}$ binding has been demonstrated and its activity probably accounts for spontaneous $\mathrm{Ca}^{2+}$ puffs emerging from the contractile vacuole complex (Fig. 6) where these channels have been localized at the light microscope and EM level (Ladenburger et al. 2006). In our belief, this PtCRC serves the partial reflux of $\mathrm{Ca}^{2+}$ which in its majority is released by expulsion (Stock et al. 2002). Sequestration is probably based on a $\mathrm{Ca}^{2+} / \mathrm{H}^{+}$antiporter (not yet identified), coupled to the activity of the organellar V-type $\mathrm{H}^{+}$-ATPase (Fok et al. 1995; Wassmer et al. 2006). The $\mathrm{Ca}^{2+}$ reflux seen as local puffs at varying sites of the contractile vacuole complex is thought to serve fine-tuning of cytosolic $\left[\mathrm{Ca}^{2+}\right]$ (Ladenburger et al. 2006) in analogy with systemic regulation processes in our kidneys. PtCRC-Il-type $\operatorname{lnsP}_{3} R$ R are constitutively active a fact detected only later on also in DT40 lymphocytes (Cárdenas et al. 2010).

PtCRC-IV-type CRCs, devoid of a $\operatorname{lns}_{3}$ binding domain, are localized to that part of the alveolar sacs that faces the closely apposed cell membrane, as found by immuno-gold EM localization (Ladenburger et al. 2009; see Fig. 7). Analysis of these CRCs included trichocyst exocytosis stimulation with the secretagogue AED (Plattner et al. 1984, 1985) as well as with the RyR activators caffeine (Klauke and Plattner 1998) and with 4-chloro-m-cresol (Klauke et al. 2000). The basis was $\mathrm{Ca}^{2+}$ imaging in response to AED (Klauke and Plattner 1997), to caffeine (Klauke and Plattner 1998; Länge et al. 1996) and to 4-chloro-m-cresol as well as the demonstration of a SOC mechanism (Klauke et al. 2000), complemented by EDX analysis (Hardt and Plattner 2000). We then combined PtCRC-IV silencing with trichocyst exocytosis stimulation and $\mathrm{Ca}^{2+}$ imaging (Ladenburger et al. 2009). Both were inhibited. A standard assay to identify a $C R C$ as a RyR, as routinely used with higher eukaryotes, would be $\mathrm{Ca}^{2+}$-dependent ${ }^{3} \mathrm{H}$-ryanodine binding (Zucchi and Ronca-Testoni 1997). As this depends on several boundary conditions and as there is no defined motif for ryanodine binding, furthermore considering the frequently aberrant pharmacology of ciliates (Plattner et al. 2009), it is not surprising that such binding cannot be registered (Plattner, unpubl. observ.).

To summarize, the following aspects qualify CRCs type IV as RyRs (Ladenburger et al. 2009). (i) As mentioned, they are activated by typical activators of RyR-type CRCs, i.e. caffeine and 4-chloro-m-cresol. (ii) The $\mathrm{Ca}^{2+}$ signal recorded with fluorochromes parallels trichocyst release. (iii) The signal is greatly reduced when PtCRC-IV channels are silenced, as is their stimulated trichocyst exocytosis. (Note that in these experiments $\left[\mathrm{Ca}^{2+}\right]_{0}$ has been quenched to a calculated value slightly below $\left[\mathrm{Ca}^{2+}\right]_{i}^{\text {rest }}$ to avoid superposition of $\mathrm{Ca}^{2+}$ influx, as described below.) (iv) We have predicted six transmembrane domains for PtCRC-IV (Ladenburger and Plattner 2011), rather than four
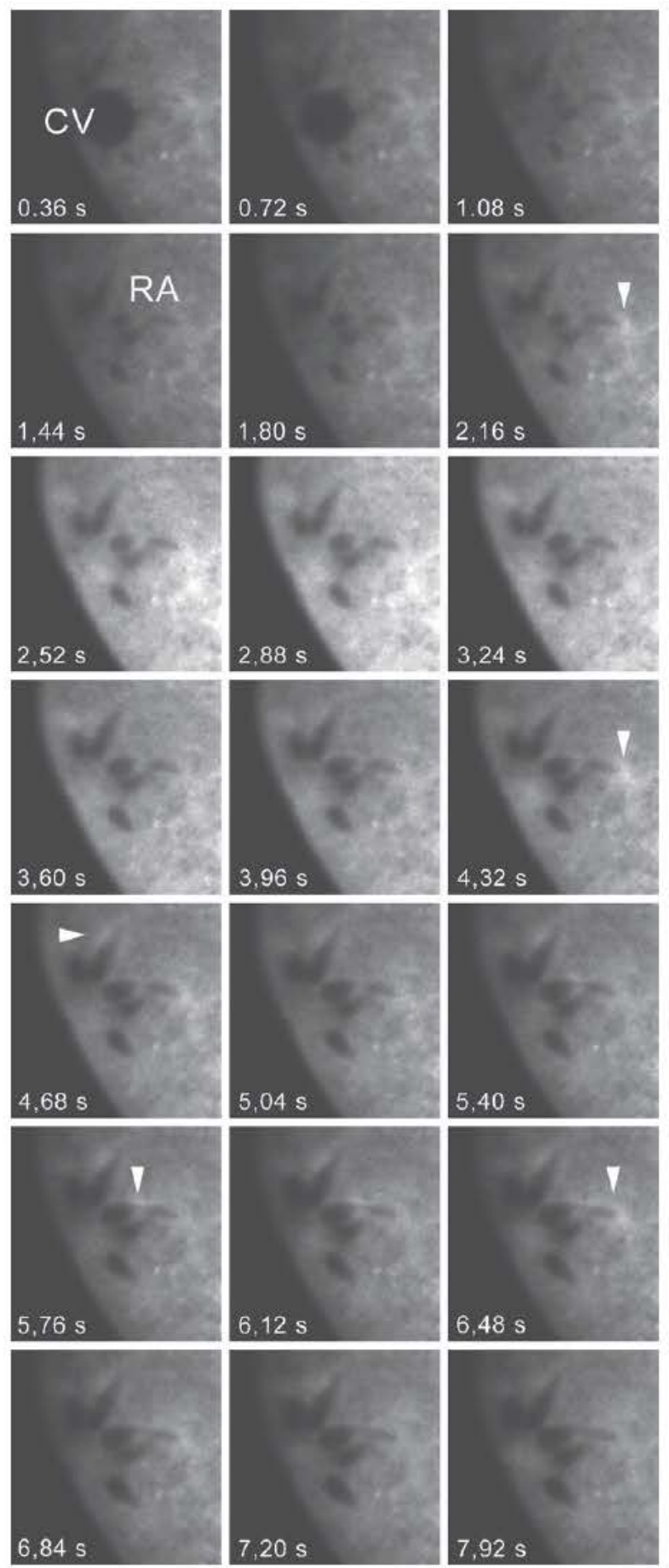

Figure 6 Fluorochrome imaging of spontaneous $\mathrm{Ca}^{2+}$ puffs along radial arms of the contractile vacuole complex in a non stimulated $P a r$ amecium tetraurelia indicates constitutively active PtCRC $\| 1 / 1 n s P_{3} R$. The cell was injected with the fluorochrome Fluo 4 coupled to dex tran. Note at arrowheads transient $\mathrm{Ca}^{2+}$ puffs along the radial arms (RA) emanating from the contractile vacuole (CV). Lower left in each frame: actual recording time. From Ladenburger et al. (2006). 


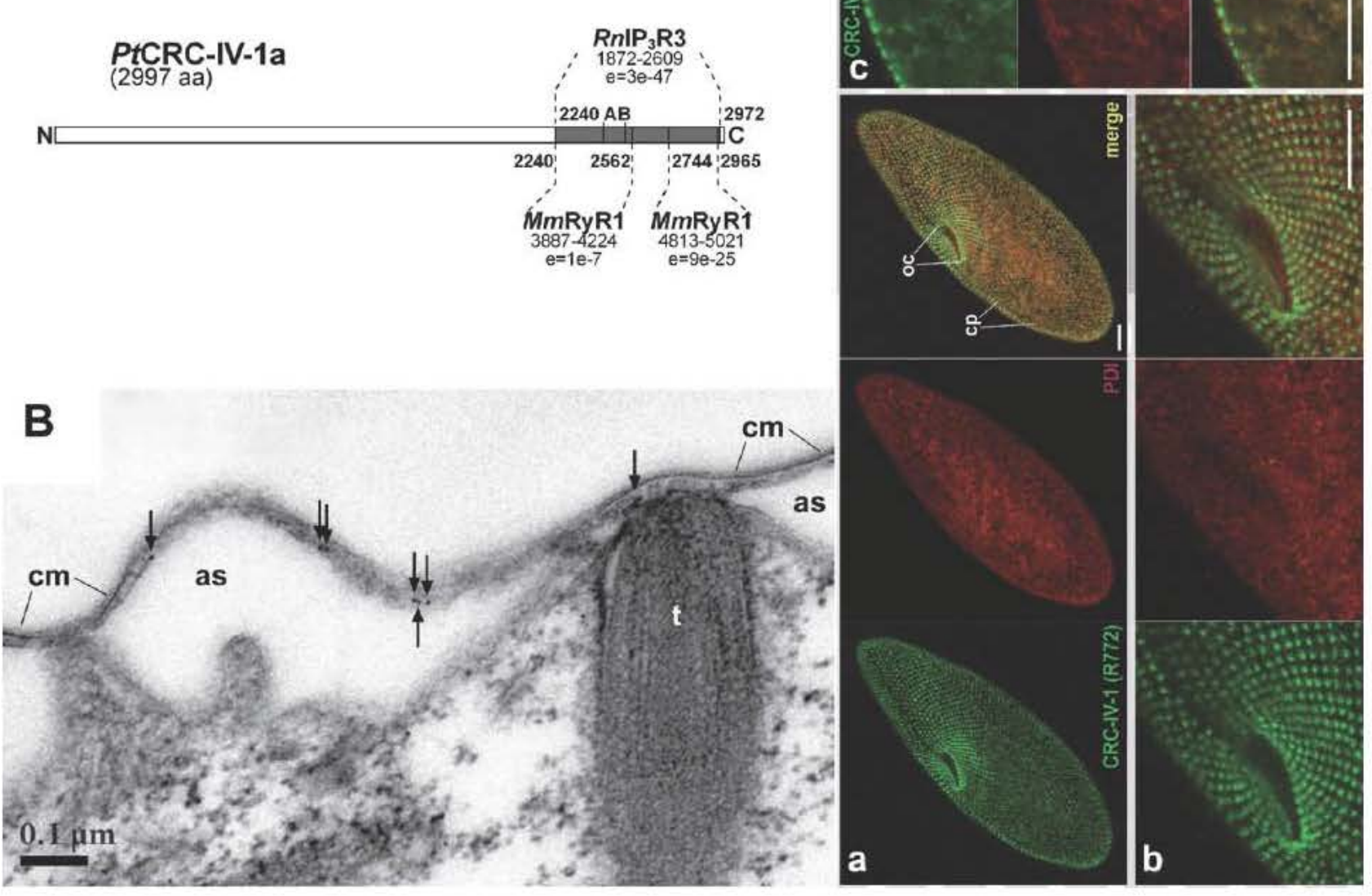

Figure 7 RyR like protein in Paramecium tetraurelia, termed PtCRC IV. (A) presents the structure and size of subtype 1a (closely resembling 1b), regions of similarity with RyR type 1 from mouse (MmRyR1) and InsP $P_{3} R$ type 3 from rat $\left(R n I P_{3} R 3\right)$ as well as the region of PtCRC IV 1a selected for antibody (AB) production. Numbers up to 5,021 indicate amino acid residues of the respective protein included in the comparison of different CRCs: 2,997 indicates the total number of amino acids in PICRC IV 1a. The evalues indicate a measure for reliability of identification of specific regions of the PtCRC IV 1a protein in comparison to $R M I P_{3} R$ or $M m I P_{3} R$ (highest reliability; e $3 e^{-47}$, i.e. $3 e^{-47}$ error probability). (B) is from immuno gold EM localization showing label (arrows) along the outer part of the alveolar sacs (as) membrane below the cell membrane (cm); $t$ marks a trichocyst. (C) Immunofluorescence; (CC) documents the localization of PtCRC IV 1 by the antibody (type R722, as specified in IBI) to the ER (characterized by ER specific protein disulfide isomerase [PDI]), (Ca,b) shows the localization to alveolar sacs (devoid of PDI). Symbols: cp cytoproct region, oc oral cavity. Scale bars $10 \mu \mathrm{m}$. (A C) are from Ladenburger et al. (2009).

as usually assumed for RyRs (Williams et al. 2001). However, this does not contradict our identification as RyRs because (i) this number has remained controversial until recently (Zalk et al. 2007), (ii) our assumption is based on the most recent comprehensive computational analysis of such domains (Bernsel et al. 2009) and (iii) most recent computational analysis of mammalian RyRs has also predicted six transmembrane domains (Ramachandran et al. 2013). Thus, together with InsP $P_{3} R$-type PtCRCs, we assume six transmembrane domains for all PtCRCs.

\section{Coupling of $\mathrm{Ca}^{2+}$ mobilization from alveolar sacs and $\mathrm{Ca}^{2+}$ influx}

As mentioned, the emptying of the cortical stores (alveolar sacs) during trichocyst exocytosis stimulation is superim- posed by an influx of $\mathrm{Ca}^{2+}$ from the outside medium, $\mathrm{SOC}(\mathrm{E})$. This has been inferred from electrophysiology (Erxleben and Plattner 1994), fluorochrome analyses under conditions specifically appropriate to document SOC (Klauke et al. 2000) and EDX analysis of stimulated wildtype cells during $\left[\mathrm{Ca}^{2+}\right]_{0}$ quenching in the medium (Hardt and Plattner 2000); see Fig. 5. Furthermore, EDX analysis of a mutant strain devoid of any $\mathrm{Ca}^{2+}$ influx clearly excluded a CICR (Mohamed et al. 2002). In summary, these analyses revealed that $\mathrm{Ca}^{2+}$ release from the alveolar sacs contributes, though only a minor fraction, to the total $\mathrm{Ca}^{2+}$ signal formed during trichocyst exocytosis, and that it serves as a kind of ignition. The whole arrangement serves precise signaling focussed on exocytosis sites: The CRCs face the cell membrane (Ladenburger et al. 2009), whereas the SERCA faces the cell center (Plattner et al. 
1999). In Fig. 8, $\mathrm{Ca}^{2+}$ signal spreading in the cell cortex occurring during exocytosis stimulation is compared with the restriction of $\mathrm{Ca}^{2+}$ signaling to cilia during depolarization. As signal spill over occurs only centrifugally from the cell soma into cilia, but not centripetally from cilia into the soma (Husser et al. 2004) cilia normally remain functionally clearly decoupled from the soma. As discussed below, this is functionally meaningful. By contrast, neither $\mathrm{Ca}^{2+}$ injection (Klauke and Plattner 1997), nor a sudden increase in $\left[\mathrm{Ca}^{2+}\right]_{0}$ (Erxleben et al. 1997) entail exocytosis, although both procedures yield an overall $\mathrm{Ca}^{2+}$ signal.

With human T-lymphocytes, a $\mathrm{SOC}(\mathrm{E})$ mechanism has been described that involves RyRs and similar coupling (Thakur et al. 2012), just as we found with Paramecium. Here, alveolar sacs contain PtCRC-IV channels (Fig. 7) and these are relevant for this signaling pathway (Ladenburger et al. 2009). Disappointingly other components contributing to this signaling mechanism, such as Stim and Orai (Cahalan 2009; Wu et al. 2007), could not be detected in the Paramecium database.

\section{Mitochondria as $\mathrm{Ca}^{2+}$ stores}

Mitochondria can rapidly take up $\mathrm{Ca}^{2+}$ by a uniporter (Hajnóczky and Csordás 2010) which has been characterized on a molecular scale in mammalian cells only quite recently (Raffaello et al. 2012). Release of $\mathrm{Ca}^{2+}$ is mediated by a $\mathrm{Ca}^{2+} / \mathrm{Na}^{+}$exchanger (Palty and Sekler 2012). Although a homolog of the $\mathrm{Ca}^{2+}$ uniporter has been detected in the Tetrahymena genome (Bick et al. 2012), no molecular

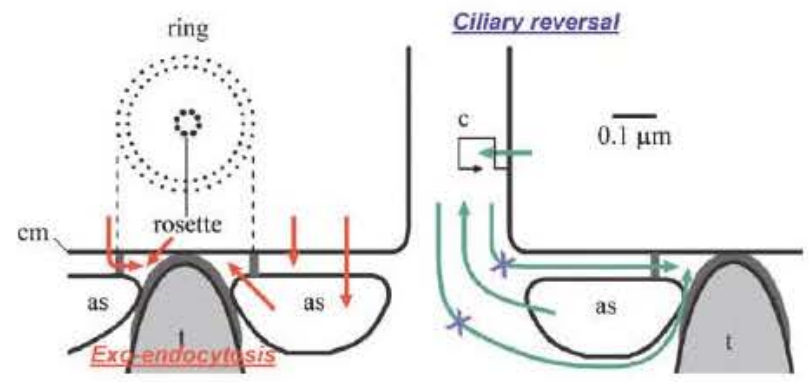

Figure $8 \mathrm{Ca}^{2+}$ fluxes occurring in Paramecium tetraurelia cells during stimulated trichocyst (t) exocytosis (red arrows) and during ciliary reversal induction (green arrows), as derived from various work cited in the text. Left part: upon exocytosis stimulation, $\mathrm{Ca}^{2+}$ is released from alveolar sacs (as) in a first step, followed by influx of $\mathrm{Ca}^{2+}$ from the outside medium (SOC). The type of influx channels, their precise localization with regard to the exocytosis site (characterized by freeze fracture particle assemblies, ring and rosette) in the cell membrane (cm) and how they are linked to alveolar sacs is not known. Right part: reversal of the beat direction of cilia (c) is initiated by an influx of $\mathrm{Ca}^{2+}$ via voltage dependent channels in the ciliary membrane; the hooky arrow (black) symbolizes the negative feedback, as the increased organellar $\left[\mathrm{Ca}^{2+}\right]$ inhibits further $\mathrm{Ca}^{2+}$ influx. Green arrows emerging from the cilium are crossed to indicate that no signal spill over to exocytosis sites occurs, whereas spill over in centrifugal direc tion does occur when $\mathrm{Ca}^{2+}$ is mobilized from alveolar sacs, e.g. during exocytosis stimulation. For further explanations, see text. details are known for the $\mathrm{Ca}^{2+} / \mathrm{Na}^{+}$antiporter in ciliates. (Note that occurrence of partial sequences of such antiporters in the Paramecium database would not allow any stringent identification as such molecules may be operating at different sites of the cell.) However, in EDX analyses following timed quenched-flow/cryofixation during different times of AED-stimulation of trichocyst exocytosis (Fig. $5 \mathrm{C}$ ), we see a swift increase in [Ca] in mitochondria and a decay within fractions of a second (Hardt and Plattner 2000). By contrast, parallel imaging of $\left[\mathrm{Ca}^{2+}\right]$ by rhodamine fluorescence shows a much slower decay with a $t_{1 / 2}$ of $\sim 3 \mathrm{~min}$ (Plattner et al. 2012). The EDX data fit well the rapid activity of a uniporter and a slower release mechanism. The $\mathrm{Ca}^{2+}$ retained in mitochondria in a soluble form (seen by rhodamine) may stimulate some dehydrogenases of the tricarboxylic acid cycle (Tarasov et al. 2012) also in Paramecium (see "Energetic aspects").

\section{Behavioral responses paralleled by $\mathrm{Ca}^{2+}$ signaling}

As already outlined above, Paramecium reverses the direction of its active ciliary stroke in response to a $\mathrm{Ca}^{2+}$ influx from the medium into cilia. In nature this is induced by activation of anteriorly enriched mechanosensitive $\mathrm{Ca}^{2+}$ influx channels (Eckert and Brehm 1979). This causes cell membrane depolarization which in turn activates voltagegated $\mathrm{Ca}^{2+}$ channels. Remarkably, these two channel types are located in different domains, i.e. the somatic (nonciliary) and the ciliary membrane, respectively (Machemer and Ogura 1979). (Molecular mechanisms under consideration are discussed below.) Under physiological conditions, there is no spill over of $\mathrm{Ca}^{2+}$ into the soma (Husser et al. 2004), except when cells are overstimulated (Plattner et al. 2006). By contrast, massive trichocyst exocytosis stimulation causes the $\mathrm{Ca}^{2+}$ signal to spill into the cilia (Husser et al. 2004), thus causing ciliary reversal (Knoll et al. 1992; Plattner et al. 1984, 1985). This involves formation of cyclic GMP (Knoll et al. 1992; Yang et al. 1997 ) by a $\mathrm{Ca}^{2+} /$ calmodulin-activated guanylate cyclase (Schultz and Klumpp 1993) and cGMP exerts an effect via a protein kinase G, PKG (Ann and Nelson 1995). This effect remains to be determined in detail. Both, the guanylate cyclase and the PKG are localized to cilia (Ann and Nelson 1995; Linder et al. 1999). In vivo, the combination of both mechanisms, trichocyst release and ciliary reversal, can be advantageous to escape the attack of predatory ciliates (Knoll et al. 1991b) a defense mechanism detected by Harumoto and Miyake (1991).

Another phenomenon is the periodically alternating backward and forward swimming (each for $\sim 8 \mathrm{~s}$ ) in response to exogenously added GTP, but not other nucleotides (Clark et al. 1993). This is paralleled by periodic changes in $\left[\mathrm{Ca}^{2+}\right]_{i}$ signals (Sehring and Plattner 2004). Based on inhibitor studies, the source of $\mathrm{Ca}^{2+}$ underlying this signal was attributed to alveolar sacs (Wassenberg et al. 1997). Considering that the pharmacology used is aberrant in Paramecium (Plattner et al. 2009) one may envisage some other stores which are important particularly for the first peak seen with a fluorochrome after GTP stimulation (Sehring and Plattner 2004). 
Which one of the many organelles endowed with CRCs (see below) this would be has not been determined as yet. The physiological meaning of this reaction is hypothetic, e.g. it may be a response to increased population density (Sehring and Plattner 2004). The type of a likely purinergic receptor remains to be analyzed. No such receptors are known for GTP (Coddou et al. 2011) and only few protozoa are known to contain purinergic receptors (Burnstock and Verkhratsky 2009).

\section{$\mathrm{Ca}^{2+}$ sensors and effectors in Paramecium}

Does calmodulin play a role in $\mathrm{Ca}^{2+}$ signal transduction in Paramecium? Calmodulin is localized to cilia and to the docking sites of trichocysts (Momayezi et al. 1986). Defective calmodulin impedes the assembly of functional trichocyst exocytosis sites (Kerboeuf et al. 1993). However, very specific anticalmodulin drugs (inhibitors) which are also active in Paramecium do not inhibit trichocyst exocytosis (Erxleben and Plattner 1994). All this is compatible with the relevance of calmodulin for the assembly of fusion sites in mammalian cells (Junge et al. 2004), although a direct activity during fusion is unlikely.

In cilia calmodulin-binding proteins are in part associated with the axoneme and in part with the membrane (Evans and Nelson 1989). A role of the hierarchial occupancy of the $\mathrm{Ca}^{2+}{ }^{2}$-binding loops, I IV, by $\mathrm{Ca}^{2+}$ or alternatively by $\mathrm{Mg}^{2+}$ in the near carboxy-terminal loops has been discussed in the context of ciliary reversal (Machemer and Teunis 1996). In fact, such antagonism affects binding to target molecules (Jama et al. 2011). Nevertheless, in cilia this mechanism remains speculative, as there are still other candidates for $\mathrm{Ca}^{2+}$ signal transfer (Bonini et al. 1991). One important candidate is ciliary centrin as it regulates voltage-dependent $\mathrm{Ca}^{2+}$ channels (Gonda et al. 2007); here, the occupancy of the carboxy-terminal EF-hand loop of centrin, rather than of calmodulin, proved important.

Although any direct role for calmodulin in signal transfer, if any, appears rather restricted, calmodulin can modulate signal transfer in many regards. Let us look for an indirect activity calmodulin may exert in Paramecium via calcineurin.

Multiple functions may be assigned to some protein phosphatases including calcineurin. Its catalytic subunit A contains a binding site for subunit $B$ and for calmodulin, as well as an autoinhibitory domain (Klee et al. 1998; Rusnak and Mertz 2000). Subunit B binds $\mathrm{Ca}^{2+}$ and the binding site for subunit $B$ at subunit $A$ is highly conserved also in Paramecium (Fraga et al. 2010). Calcineurin can be designated a multipurpose phosphatase. For instance, the $\mathrm{Ca}^{2+} /$ calmodulin complex inactivating L-type $\mathrm{Ca}^{2+}$-influx channels in hippocampal pyramidal neurons is actually inactivated via dephosphorylation by calcineurin (Oliveria et al. 2012). Similarly, in Paramecium, silencing of some of the calcineurin paralogs affects stimulated backward swimming (Fraga et al. 2010). Although the underlying mechanisms has not been elucidated as yet one should recall that ciliary $\mathrm{Ca}^{2+}$-influx channels in Paramecium are also inhibited by a $\mathrm{Ca}^{2+}$ /calmodulin complex (see above). The same is true of inhibition of trichocyst exocytosis by microinjected antibodies against mammalian calcineurin (recognizing homologs in Paramecium) (Momayezi et al. 1987). Similar effects have been achieved with a variety of mammalian secretory systems; as discussed by Fraga et al. (2010), this may be caused by multiple effects of calcineurin. For instance, CRCs of the RyR-type in different cell types are sensitive to calcineurin, or calcineurindirected drugs (Brillantes et al. 1994; Wagenknecht and Radermacher 1997; Xiao et al. 1997). Whether this is also true of PtCRC-IV channels associated with the alveolar sacs in Paramecium (Ladenburger et al. 2009) remains to be elucidated.

The best, long known function of calcineurin is the activation of transcription factors (Shenolikar 1994), e.g. during activation of T-lymphocytes. May a similar pathway of gene activation also take place in ciliates? In ciliates, a massive $\mathrm{Ca}^{2+}$ increase during stimulated exocytosis may give a signal to the nucleus. Though in Tetrahymena little is known about $\mathrm{Ca}^{2+}$ signaling per se, the situation may be quite similar to that we described in Paramecium. Under such conditions, e.g. massive mucocyst exocytosis stimulation, the transcription of many genes is upregulated (Haddad and Turkewitz 1997). More recently this has also been found in Paramecium (Arnaiz and Sperling 2011).

Another long known aspect is the dephosphorylation of dynamin for driving clathrin-coated vesicle endocytosis in mammalian cells (Marks and McMahon 1998). In agreement with the frequently reported fact that protein phosphatases are localized close to their site of action (Inagaki et al. 1994) we found calcineurin considerably enriched on parasomal sacs of Paramecium (Momayezi et al. 2000). In Tetrahymena, these sites have been shown to contain a dynamin-like protein (Elde et al. 2005).

CDPKs contain a calmodulin-like domain integrated in the kinase molecule (Sussmann et al. 1996). They are specific inventions of protists and higher plants. In Paramecium CDPKs phosphorylate several ciliary $\mathrm{Ca}^{2+}$-binding proteins as well as centrin of the infraciliary lattice (Kim et al. 2002). The latter may be relevant for cell surface structuring and the centrin-enriched lattice provides a sink (immobile buffer) for $\mathrm{Ca}^{2+}$ after massive exocytosis stimulation (Sehring et al. 2009). As according to database mining the number of protein kinases, including $\mathrm{Ca}^{2+}$-sensitive ones, is unexpectedly large (Bemm et al. 2009) one has to expect for protein kinases many more functions pertinent to $\mathrm{Ca}^{2+}$ signaling.

Although the basic mechanism of synaptotagmin as a $\mathrm{Ca}^{2+}$ sensor for membrane fusion is common to all higher eukaryotes, a synaptotagmin equivalent has not been identified unambiguously in protozoa as yet. In Paramecium, the database contains similar proteins including one type with eight (rather than two in orthodox synaptotagmin) C2-domains which otherwise is most similar to synaptotagmin (Plattner et al. 2012). The wide variety of CRCs we find in Paramecium may provide $\mathrm{Ca}^{2+}$ for locally different sensors with different $\mathrm{Ca}^{2+}$ sensitivity, as known from synaptotagmin in mammalian cells (Sugita et al. 2002). 


\section{Energetic aspects}

Exocytosis stimulation entails a significant decrease in total [ATP] over $\sim 5 \mathrm{~s}$ and a slower increase within $\sim 30 \mathrm{~s}$ (Vilmart-Seuwen et al. 1986; Müller et al. 2002). One may argue that the cell invests ATP to get rid of an excess of $\mathrm{Ca}^{2+}$, but this aspect may be controlled in several ways. One aspect is the occurrence of dephosphorylation of a $63 \mathrm{kDa}$ phosphoprotein, pp63, within $80 \mathrm{~ms}$, i.e. the time required for synchronous exocytosis (Zieseniss and Plattner 1985; Höhne-Zell et al. 1992). This pp63 has been identified as phosphoglucomutase (Hauser et al. 1997), with two isoforms occurring in Paramecium. It is a substrate of calcineurin (Kissmehl et al. 1996, 1997a) and re-phosphorylation is executed by a casein kinase which quite unusually is inhibited by $\mathrm{Ca}^{2+}$ (Kissmehl et al. 1997b; Vetter et al. 2003). Thus, dephosphorylation is very fast, although rephosphorylation is retarded in the course of $\mathrm{Ca}^{2+}$ signaling. We have only indirect evidence that this interplay may keep phosphoglucomutase in a dephosphorylated active state, as hypothesized by Plattner and Kissmehl (2005), thus allowing it to feed glucose substrate into the glycolytic pathway for further use in mitochondria. From all we know about mitochondrial $\mathrm{Ca}^{2+}$ in Paramecium and the general effect of a $\left[\mathrm{Ca}^{2+}\right]$ increase in mitochondria on energetics (see above) we have to expect an increase in ATP production also in these organelles. Thus, events in the cytosolic compartment might be coupled with the effect of mitochondrial $\left[\mathrm{Ca}^{2+}\right]$ increase during exocytosis stimulation (see above).

\section{EVOLUTIONARY ASPECTS, CONCLUSIONS AND OPEN QUESTIONS}

\section{Evolutionary aspects}

Many details of cellular $\mathrm{Ca}^{2+}$ dynamics are currently known from Paramecium, probably more than from most other protozoa. The question arises when in evolution such a complex signaling system may have been installed. Alveolates are estimated to have emerged about $2 \times 10^{9} \mathrm{yr}$ ago (Hedges et al. 2004), ciliates about $850 \times 10^{6}$ (Douzery et al. 2004), Apicomplexa about $550 \times 10^{6}$ (Douzery et al. 2004) and their current parasitic close relatives about $13 \times 10^{6}$ yr ago (Ricklefs and Outlaw 2010). We may reasonably assume that the requirement of $\mathrm{Ca}^{2+}$, alone for the needs of complex intracellular trafficking pathways, had to be matched already at the beginning of the evolution of Alveolates (Plattner and Verkhratsky 2013). In the other extreme, Apicomplexa have changed their $\mathrm{Ca}^{2+}$ signaling system with several respects, as it is not possible, for instance, to identify any Ins $\mathrm{P}_{3} \mathrm{Rs}$ or RyR-like proteins (Plattner et al. 2012).

From the multitude of rather similar, but in detail divergent CRCs in Paramecium, one may conclude that an ancient precursor of current-time CRCs, types $\operatorname{Ins}_{3} R$ and RyR, has existed already in early times of eukaryotic evolution. There may have taken place some convergent evolution in detail to match the requirements of $\mathrm{Ca}^{2+}$ conductance for membrane interactions and other phenomena requiring regulation (Plattner and Verkhratsky 2013). Mechanosensitive $\mathrm{Ca}^{2+}$ channels may also be an ancient inheritage, not only to guide swimming cells by ciliary reversal (see above) to areas devoid of obstacles, but also to regulate internal tensions occurring, for instance, in the contractile vacuole complex and in food vacuoles (phagolysosomes). We speculate along these lines because we find Stomatin in such membrane areas and because this scaffolding protein is frequently associated with mechanosensitive channels in metazoans (Reuter et al. 2013).

Altogether it appears that in parallel to the complicated vesicle trafficking machinery also a complicated $\mathrm{Ca}^{2+}$ signaling machinery, with all molecular details (or most of them), will have evolved in ciliates.

\section{CONCLUSIONS}

In Paramecium, the inventory of $\mathrm{Ca}^{2+}$ regulating and $\mathrm{Ca}^{2+}$ regulated molecules are present in full. A plethora of $\mathrm{Ca}^{2+}$ channels has been found. Those in the cell membrane have been extensively studied over decades by electrophysiologists, those inside the cell only quite recently. The spectrum of $\mathrm{Ca}^{2+}$-channels encompasses mechanosensitive and voltage-dependent channels, InsP ${ }_{3} R s$ and RyR-like CRC proteins. Also characteristic $\mathrm{Ca}^{2+}$-ATPases/ pumps, type PMCA and SERCA are present. This inventory is complemented by $\mathrm{Ca}^{2+}$ sensor proteins, such as calmodulin and by CDPK and phosphatases, with the exception of synaptotagmin. Although better known from plants and recently also from protozoan parasites, including Apicomplexa, kinases type CDPK most probably serve many functions also in Paramecium. See Fig. 9 for a summary of basic mechanisms of $\mathrm{Ca}^{2+}$ signaling and homeostasis, and Table 1 for the localization of relevant components.

Despite some progress in work concerning $\mathrm{Ca}^{2+}$ in Paramecium many questions remain to be solved. The following are some examples:

- How is the signal perceived and transduced when exocytosis is stimulated by AED?

- Is there a classical G-protein-coupled 7-transmembrane protein receptor with coupling to PLC?

- Which is the identity of the $\mathrm{Ca}^{2+}$-sensor for membrane fusion, in the absence of synaptotagmin?

- How are alveolar sacs coupled to the cell membrane, considering the absence of Orai and Stim proteins in the Paramecium database?

- Although in Paramecium a calreticulin-like protein could be localized in the ER and a calsequestrin-like protein in the alveolar sacs using monospecific antibodies, their molecular characterization remains to be established.

- Are all of those PtCRCs which, according to their sequence similarities, are closely related to $\operatorname{lns}_{3} R s$ and RyRs functionally active? And how are they locally activated? 


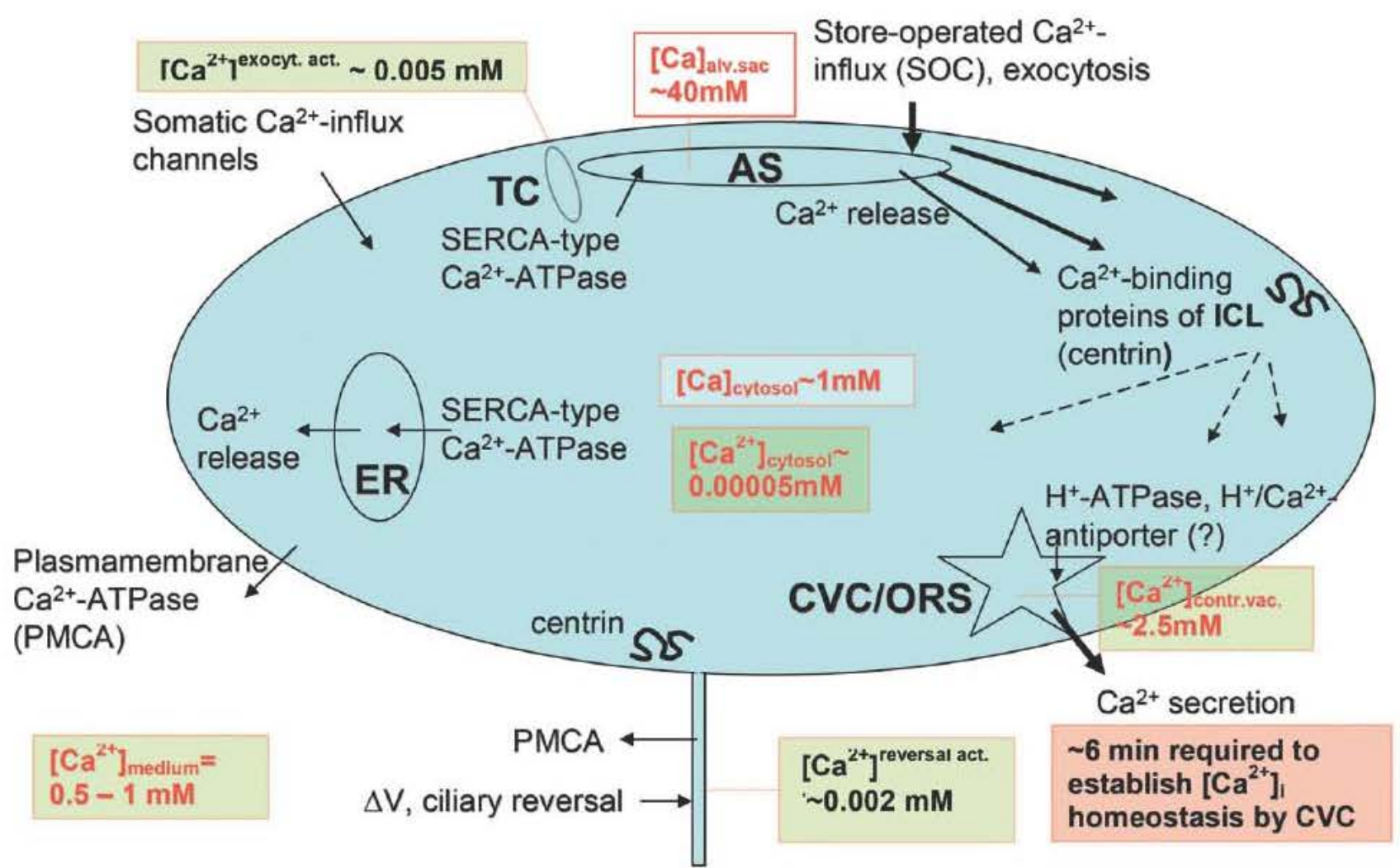

Figure 9 Survey of $\mathrm{Ca}^{2+}$ storage, mobilization, and handling, as established for Paramecium cells. The structures considered are alveolar sacs (AS), the ER and cilia (with depolarization dependent $[\Delta \mathrm{V}] \mathrm{Ca}^{2+}$ influx channels), the infraciliary lattice (ICL) as an immobile $\mathrm{Ca}^{2+}$ buffer system as well as the contractile vacuole complex (CVC ORS, osmoregulatory system). Boxes indicate total [Ca] and dissolved [Ca $\left.{ }^{2+}\right]$, respectively, in dif ferent areas of the cell. Pumps/transporters available for the downregulation of $\mathrm{Ca}^{2+}$ encompass PMCA, SERCA and, indirectly, the $\mathrm{H}^{+}$ATPase in conjunction with a hypothetical $\mathrm{H}^{+} / \mathrm{Ca}^{2+}$ (or similar) antiporter for secondary active $\mathrm{Ca}^{2+}$ transport into the contractile vacuole complex, followed by secretion during contractile vacuole systole. Differences in actual $\mathrm{Ca}^{2+}$ concentrations between compartments are significant, thus allowing directed $\mathrm{Ca}^{2+}$ fluxes. In alveolar sacs, [Ca] of $-40 \mathrm{mM}$ (Hardt and Plattner 2000 ) can be rapidly mobilized to release $\mathrm{Ca}^{2+}$, but lumenal $\left[\mathrm{Ca}{ }^{2+}\right]$ is not known. Any increased cortical $\mathrm{Ca}^{2+}$ is rapidly bound to centrin of the infraciliary lattice (Sehring et al. 2009); from there Ca ${ }^{2+}$ dissipates into the cytosol for extrusion mainly via the contractile vacuole system (shown by the retardation of $\left[\mathrm{Ca}^{2+}\right]_{i}$ downregulation by inhibiting $\mathrm{H}^{+}$ATPase activity Plattner et al. 2012). Thus, after exocytosis stimulation, $\mathrm{CCa}^{2+} \mathrm{l}_{\mathrm{i}}$ homeostasis can be re established within -6 min (Ladenburger et al. 2006). $\left[\mathrm{Ca}^{2+}\right]$ at trichocyst (TC) exocytosis sites during stimulation has been estimated by Klauke and Plattner (1997), that in cilia during ciliary reversal has been derived from electrophysiology (Oertel et al. 1977), as summarized by Plattner et al. (2006). Note that centrin, associated with basal bodies, can rapidly immobilize any $\mathrm{Ca}^{2+}$ dissipating from the ciliary basis. For further explanations, see text.

- Any other $\mathrm{Ca}^{2+}$ channels addressed here remain to be identified at the molecular level.

- Does the ciliary membrane contain a PMCA?

- Does the contractile vacuole complex contain a $\mathrm{Ca}^{2+}$ ATPase and a $\mathrm{Ca}^{2+} / \mathrm{H}^{+}$antiporter?

- What precisely is the function of calmodulin at secretory organelle docking sites and during ciliary reversal?

- Which are the specific functions, out of probably many, of calcineurin?

- Which specific functions exert CDPKs in $\mathrm{Ca}^{2+}$ signaling?

There remains enough work to be performed in the decades to come, provided funding of basic research will still be available for aspects like these. Surely, it may be an argument that work with a harmless ciliate, which can be easily cultured and which offers considerable advantage by its regular design, may also give a handle to similar problems with parasitic protozoa which are much less easy to work with. I mention this because politicians and universities may decide more and more that work without immediate practical use may not be supported further on.

\section{ACKNOWLEDGMENTS}

The author's work cited herein has been supported by the German Research Council (Deutsche Forschungsgemeinschaft).

\section{LITERATURE CITED}

Ann, K. S. \& Nelson, D. L. 1995. Protein substrates for cGMP dependent protein phosphorylation in cilia of wild type and ata 
lanta mutants of Paramecium. Cell Motil. Cytoskeleton, 30:252 260.

Arnaiz, O. \& Sperling, L. 2011. ParameciumDB in 2011: new tools and new data for functional and comparative genomics of the model ciliate Paramecium tetraurelia. Nucleic Acid Res., 39: D632 D636.

Becherer, U., Moser, T., Stuhmer, W. \& Oheim, M. 2003. Calcium regulates exocytosis at the level of single vesicles. Nat. Neurosci., 6:846 853

Becherer, U., Medart, M. R., Schirra, C., Krause, E., Stevens, D. \& Rettig, J. 2012. Regulated exocytosis in chromaffin cells and cytotoxic T lymphocytes: how similar are they? Cell Calcium, 52:303 312.

Beisson, J., Clerot, J. C., Fleury Aubusson, A., Garreau de Loub resse, N., Ruiz, F. \& Klotz, C. 2001. Basal body associated nucleation center for the centrin based cortical cytoskeletal net work in Paramecium. Protist, 152:339 354

Bemm, F., Schwarz, R., Forster, F. \& Schultz, J. 2009. A kinome of 2600 in the ciliate Paramecium tetraurelia. FEBS Lett., 583:3589 3592

Bernsel, A., Viklund, H., Hennerdal, A. \& Elofsson, A. 2009. TOP CONS: consensus prediction of membrane protein topology. Nucleic Acid Res., 37:W465 W468

Berridge, M. J., Bootman, M. D. \& Roderick, H. L. 2003. Calcium signalling: dynamics, homeostasis and remodelling. Nat. Rev. Mol. Cell Biol., 4:517 529

Bick, A., Calvo, S. E. \& Mootha, V. K. 2012. Evolutionary diversity of the mitochondrial calcium uniporter. Science, 336:886.

Bilinski, M., Plattner, H. \& Matt, H. 1981. Secretory protein de condensation as a distinct, $\mathrm{Ca}^{2+}$ mediated event during the final steps of exocytosis in Paramecium cells. J. Cell Biol., 88:179 188

Boehning, D. F. 2010. Molecular architecture of the inositol 1,4,5 trisphosphate receptor pore. Curr. Top. Membr., 66C:191 207.

Bonini, N. M., Evans, T. C., Miglietta, L. A. \& Nelson, D. L. 1991. The regulation of ciliary motility in Paramecium by $\mathrm{Ca}^{2+}$ and cyclic nucleotides. Adv. Second Messenger Phosphoprotein Res., 23:227 272.

Brehm, P. \& Eckert, R. 1978. Calcium entry leads to inactivation of calcium channel in Paramecium. Science, 202:1203 1206.

Brillantes, A. B., Ondrias, K., Scott, A., Kobrinsky, E., Ondriasova, E., Moschella, M. C., Jayaraman, T., Landers, M., Ehrlich, B. E. \& Marks, A. R. 1994. Stabilization of calcium release channel (ryanodine receptor) function by FK506 binding protein. Cell, 77:513 523.

Browning, J. L. \& Nelson, D. L. 1976. Biochemical studies of the excitable membrane of Paramecium aurelia. I. ${ }^{45} \mathrm{Ca}^{2+}$ fluxes across resting and excited membrane. Biochim. Biophys. Acta, 448:338 351

Burlando, B., Marchi, B., Kruppel, T., Orunesu, M. \& Viarengo, A. 1999. Occurrence of $\mathrm{Na}^{+} \mathrm{Ca}^{2+}$ exchange in the ciliate Euplotes crassus and its role in $\mathrm{Ca}^{2+}$ homeostasis. Cell Calcium, 25:153 160

Burnstock, G. \& Verkhratsky, A. 2009. Evolutionary origin of the purinergic signalling system. Acta Physiol. (Oxf.), 195:415 447.

Cahalan, M. D. 2009. STIMulating store operated $\mathrm{Ca}^{2+}$ entry. Nat. Cell Biol., 11:669 677

Cai, X. 2008. Unicellular $\mathrm{Ca}^{2+}$ signaling "toolkit" at the origin of metazoa. Mol. Biol. Evol., 25:1357 1361.

Cárdenas, C., Miller, R. A., Smith, I., Bui, T., Molgó, J., Muller, M., Vais, H., Cheung, K. H., Yang, J., Parker, I., Thompson, C. B., Birbnbaum, M. J., Hallows, K. R. \& Foskett, J. K. 2010. Essential regulation of cell bioenergetics by constitutive $\operatorname{InsP}_{3}$ receptor $\mathrm{Ca}^{2+}$ transfer to mitochondria. Cell, 142:270 283.
Christensen, K. A., Myers, J. T. \& Swanson, J. A. 2002. pH dependent regulation of lysosomal calcium in macrophages. J. Cell Sci., 115:599 607

Churamani, D., Hooper, R., Rahman, T., Brailoiu, E. \& Patel, S 2013. The $N$ terminal region of two pore channel 1 regulates trafficking and activation by NAADP. Biochem. J., 453:147 151.

Clapham, D. E. 2007. Calcium signaling. Cell, 131:1047 1058.

Clark, K. D., Hennessey, T. M. \& Nelson, D. L. 1993. External GTP alters the motility and elicits an oscillating membrane depolarization in Paramecium tetraurelia. Proc. Natl Acad. Sci. U $S$ A, 90:3782 3786

Coddou, C., Yan, Z., Obsil, T., Huidobro Toro, J. P. \& Stojilkovic, S. S. 2011. Activation and regulation of purinergic P2X receptor channels. Pharmacol. Rev., 63:641 683.

Coleman, J. R., Nilsson, J. R., Warner, R. R. \& Batt, P. 1972 Qualitative and quantitative electron probe analysis of cytoplas mic granules in Tetrahymena pyriformis. Exp. Cell Res. $74: 207219$

Dellis, O., Rossi, A. M., Dedos, S. G. \& Taylor, C. W. 2008. Counting functional inositol 1,4,5 trisphosphate receptors into the plasma membrane. J. Biol. Chem., 283:751 755.

Docampo, R., de Souza, W., Miranda, K., Rohloff, P. \& Moreno, S. N. 2005. Acidocalcisomes conserved from bacteria to man. Nat. Rev. Microbiol., 3:251 261.

Douzery, E. J., Snell, E. A., Bapteste, E., Delsuc, F. \& Philippe, H. 2004. The timing of eukaryotic evolution: does a relaxed molec ular clock reconcile proteins and fossils? Proc. Natl Acad. Sci. U S A, 101:15386 15391

Eckert, R. \& Brehm, P. 1979. Ionic mechanisms of excitation in Paramecium. Annu. Rev. Biophys. Bioeng., 8:353 383.

Elde, N. C., Morgan, G., Winey, M., Sperling, L. \& Turkewitz, A. P. 2005. Elucidation of clathrin mediated endocytosis in Tetrahy mena reveals an evolutionarily convergent recruitment of dyn amin. PLoS Genet., 1:e52.

Erxleben, C. \& Plattner, H. 1994. $\mathrm{Ca}^{2+}$ release from subplasma lemmal stores as a primary event during exocytosis in Parame cium cells. J. Cell Biol., 127:935 945.

Erxleben, C., Klauke, N., Flotenmeyer, M., Blanchard, M. P. Braun, C. \& Plattner, H. 1997. Microdomain $\mathrm{Ca}^{2+}$ activation dur ing exocytosis in Paramecium cells. Superposition of local sub plasmalemmal calcium store activation by local $\mathrm{Ca}^{2+}$ influx. J. Cell Biol., 136:597 607.

Evans, T. C. \& Nelson, D. L. 1989. The cilia of Paramecium te traurelia contain both $\mathrm{Ca}^{2+}$ dependent and $\mathrm{Ca}^{2+}$ inhibitable cal modulin binding proteins. Biochem. J., 259:385 396.

Fang, J., Marchesini, N. \& Moreno, S. N. J. 2006. A Toxoplasma gondii phosphoinositide phospholipase C (TgPI PLC) with high affinity for phosphatidylinositol. Biochem. J., 394:417 425.

Fok, A. K., Aihara, M. S., Ishida, M., Nolta, K. V., Steck, T. L. \& Allen, R. D. 1995. The pegs on the decorated tubules of the contractile vacuole complex of Paramecium are proton pumps. J. Cell Sci., 108:3163 3170.

Fraga, D., Sehring, I. M., Kissmehl, R., Reiss, M., Gaines, R., Hin richsen, R. \& Plattner, H. 2010. Protein phosphatase 2B (PP2B calcineurin) in Paramecium: partial characterization reveals that two members of the unusually large catalytic subunit family have distinct roles in calcium dependent processes. Eukaryot. Cell, 9:1049 1063.

Galione, A., Evans, A. M., Ma, J., Parrington, J., Arredouani, A. Cheng, X. \& Zhu, M. X. 2009. The acid test: the discovery of two pore channels (TPCs) as NAADP gated endolysosomal $\mathrm{Ca}^{2+}$ release channels. Pflugers Arch., 458:869 876.

Gogendeau, D., Klotz, C., Arnaiz, O., Malinowska, A., Dadlez, M., de Loubresse, N. G., Ruiz, F., Koll, F. \& Beisson, J. 2008. Func 
tional diversification of centrins and cell morphological complex ity. J. Cell Sci., 121:65 74.

Gonda, K., Oami, K. \& Takahashi, M. 2007. Centrin controls the activity of the ciliary reversal coupled voltage gated $\mathrm{Ca}^{2+}$ chan nels $\mathrm{Ca}^{2+}$ dependently. Biochem. Biophys. Res. Commun., 362:170 176.

Grover, J. E., Rope, A. F. \& Kaneshiro, E. S. 1997. The occurrence of biogenic calcian struvite, (Mg, Ca)NH4PO4.6H2O, as intracellu lar crystals in Paramecium. J. Eukaryot. Microbiol., 44:366 373.

Haddad, A. \& Turkewitz, A. P. 1997. Analysis of exocytosis mutants indicates close coupling between regulated secretion and transcription activation in Tetrahymena. Proc. Natl Acad. Sci. U S A, 94:10675 10680

Hajnóczky, G. \& Csordás, G. 2010. Calcium signalling: fishing out molecules of mitochondrial calcium transport. Curr. Biol., 20: R888 R891.

Hardt, M. \& Plattner, H. 1999. Quantitative energy dispersive $\mathrm{X}$ ray microanalysis of calcium dynamics in cell suspensions during stimulation on a subsecond time scale: preparative and analytical aspects as exemplified with Paramecium cells. J. Struct. Biol., 128:187 199.

Hardt, M. \& Plattner, H. 2000. Sub second quenched flow/X ray microanalysis shows rapid $\mathrm{Ca}^{2+}$ mobilization from cortical stores paralleled by $\mathrm{Ca}^{2+}$ influx during synchronous exocytosis in Para mecium cells. Eur. J. Cell Biol., 79:642 652

Harumoto, T. \& Miyake, A. 1991. Defensive function of trich ocysts in Paramecium. J. Exp. Zool., 260:8492.

Hauser, K., Kissmehl, R., Linder, J., Schultz, J. E., Lottspeich, F. \& Plattner, H. 1997. Identification of isoforms of the exocytosis sensitive phosphoprotein PP63/parafusin in Paramecium tetraur elia and demonstration of phosphoglucomutase activity. Bio chem. J., 323:289 296.

Hauser, K., Pavlovic, N., Kissmehl, R. \& Plattner, H. 1998. Molec ular characterization of a sarco(endo)plasmic reticulum $\mathrm{Ca}^{2+}$ AT Pase gene from Paramecium tetraurelia and localization of its gene product to sub plasmalemmal calcium stores. Biochem. J., 334:31 38.

Hauser, K., Pavlovic, N., Klauke, N., Geissinger, D. \& Plattner, H. 2000. Green fluorescent protein tagged sarco(endo)plasmic reticulum $\mathrm{Ca}^{2+}$ ATPase overexpression in Paramecium cells: isoforms, subcellular localization, biogenesis of cortical calcium stores and functional aspects. Mol. Microbiol., 37:773 787.

Hedges, S. B., Blair, J. E., Venturi, M. L. \& Shoe, J. L. 2004. A molecular timescale of eukaryote evolution and the rise of complex multicellular life. BMC Evol. Biol., 4:2.

Hohne Zell, B., Knoll, G., Riedel Gras, U., Hofer, W. \& Plattner, H. 1992. A cortical phosphoprotein ('PP63') sensitive to exocytosis triggering in Paramecium cells. Immunolocalization and quenched flow correlation of time course of dephosphorylation with membrane fusion. Biochem. J., 286:843 849.

Husser, M. R., Hardt, M., Blanchard, M. P., Hentschel, J., Klauke, N. \& Plattner, H. 2004. One way calcium spill over during signal transduction in Paramecium cells: from the cell cortex into cilia, but not in the reverse direction. Cell Calcium, 36:349 358.

Inagaki, N., Ito, M., Nakano, T. \& Inagaki, M. 1994. Spatiotempo ral distribution of protein kinase and phosphatase activities. Trends Biochem. Sci., 19:448 452.

Jaconi, M. E., Lew, D. P., Carpentier, J. L., Magnusson, K. E., Sjogren, M. \& Stendahl, O. 1990. Cytosolic free calcium eleva tion mediates the phagosome lysosome fusion during phagocy tosis in human neutrophils. J. Cell Biol., 110:1555 1564.

Jama, A. M., Gabriel, J., Al Nagar, A. J., Martin, S., Baig, S. Z., Soleymani, H., Chowdhury, Z., Beesley, P. \& Torok, K. 2011. Lobe specific functions of $\mathrm{Ca}^{2+}$ calmodulin in $\mathrm{\alpha Ca}^{2+}$ calmodulin dependent protein kinase II activation. J. Biol. Chem., 286:12308 12316

Junge, H. J., Rhee, J. S., Jahn, O., Varoqueaux, F., Spiess, J., Waxham, M. N., Rosenmund, C. \& Brose, N. 2004. Calmodulin and Munc13 form a $\mathrm{Ca}^{2+}$ sensor/effector complex that controls short term synaptic plasticity. Cell, 118:389 401.

Kerboeuf, D. \& Cohen, J. 1990. A Ca ${ }^{2+}$ influx associated with exo cytosis is specifically abolished in a Paramecium exocytotic mutant. J. Cell Biol., 111:2527 2535.

Kerboeuf, D., Le Berre, A., Dedieu, J. C. \& Cohen, J. 1993. Calmodulin is essential for assembling links necessary for exocytotic membrane fusion in Paramecium. EMBO J., 12:3385 3390

Kim, K., Son, M., Peterson, J. B. \& Nelson, D. L. 2002. $\mathrm{Ca}^{2+}$ bind ing proteins of cilia and infraciliary lattice of Paramecium te traurelia: their phosphorylation by purified endogenous $\mathrm{Ca}^{2+}$ dependent protein kinases. J. Cell Sci., 115:1973 1984.

Kissmehl, R., Treptau, T., Hofer, H. W. \& Plattner, H. 1996. Pro tein phosphatase and kinase activities possibly involved in exo cytosis regulation in Paramecium tetraurelia. Biochem. J., 317:65 76 .

Kissmehl, R., Treptau, T., Hauser, K. \& Plattner, H. 1997a. A novel, calcium inhibitable casein kinase in Paramecium cells. FEBS Lett., 402:227 235

Kissmehl, R., Treptau, T., Kottwitz, B. \& Plattner, H. 1997b. Occurrence of a para nitrophenyl phosphate phosphatase with calcineurin like characteristics in Paramecium tetraurelia. Arch. Biochem. Biophys., 344:260 270.

Kissmehl, R., Huber, S., Kottwitz, B., Hauser, K. \& Plattner, H. 1998. Subplasmalemmal Ca stores in Paramecium tetraurelia. Identification and characterisation of a sarco(endo)plasmic retic ulum like $\mathrm{Ca}^{2+}$ ATPase by phosphoenzyme intermediate forma tion and its inhibition by caffeine. Cell Calcium, 24:193 203.

Klauke, N. \& Plattner, H. 1997. Imaging of $\mathrm{Ca}^{2+}$ transients induced in Paramecium cells by a polyamine secretagogue. J. Cell Sci., 110:975 983

Klauke, N. \& Plattner, H. 1998. Caffeine induced $\mathrm{Ca}^{2+}$ transients and exocytosis in Paramecium cells. A correlated $\mathrm{Ca}^{2+}$ imaging and quenched flow/freeze fracture analysis. J. Membr. Biol., 161:65 81

Klauke, N., Kissmehl, R., Plattner, H., Haga, N. \& Watanabe, T. 1998. An exocytotic mutant of Paramecium caudatum: mem brane fusion without secretory contents release. Cell Calcium, 23:349 360 .

Klauke, N., Blanchard, M. P. \& Plattner, H. 2000. Polyamine trig gering of exocytosis in Paramecium involves an extracellular $\mathrm{Ca}^{2+} /$ (polyvalent cation) sensing receptor, subplasmalemmal Ca store mobilization and store operated $\mathrm{Ca}^{2+}$ influx via unspecific cation channels. J. Membr. Biol., 174:141 156

Klee, C. B., Ren, H. \& Wang, X. 1998. Regulation of the calmodu lin stimulated protein phosphatase, calcineurin. J. Biol. Chem., 273:13367 13370

Kloppel, C., Muller, A., Marker, S. \& Simon, M. 2009. Two iso forms of eukaryotic phospholipase $C$ in Paramecium affecting transport and release of $\mathrm{GPI}$ anchored proteins in vivo. Eur. J. Cell Biol., 88:577 592

Klumpp, S., Kleefeld, G. \& Schultz, J. E. 1983. Calcium/calmodu lin regulated guanylate cyclase of the excitable ciliary mem brane from Paramecium. Dissociation of calmodulin by $\mathrm{La}^{3+}$ : calmodulin specificity and properties of the reconstituted guanylate cyclase. J. Biol. Chem., 258:12455 12459.

Knoll, G., Braun, C. \& Plattner, H. 1991a. Quenched flow analysis of exocytosis in Paramecium cells: time course, changes in membrane structure, and calcium requirements revealed after 
rapid mixing and rapid freezing of intact cells. J. Cell Biol., 113:1295 1304 .

Knoll, G., Haacke Bell, B. \& Plattner, H 1991b. Local trichocyst exocytosis provides an efficient escape mechanism for Parame cium cells. Eur. J. Protistol., 27:381 385.

Knoll, G., Kerboeuf, D. \& Plattner, H. 1992. A rapid calcium influx during exocytosis in Paramecium cells is followed by a rise in cyclic GMP within 1 s. FEBS Lett., 304:265 268.

Knoll, G., Grassle, A., Braun, C., Probst, W., Hohne Zell, B. \& Plattner, H. 1993. A calcium influx is neither strictly associated with nor necessary for exocytotic membrane fusion in Parame cium cells. Cell Calcium, 14:173 183.

Kung, C., Preston, R. R., Maley, M. E., Ling, K. Y., Kanabrocki, J. A., Seavey, B. R. \& Saimi, Y. 1992. In vivo Paramecium mutants show that calmodulin orchestrates membrane responses to stimuli. Cell Calcium, 13:413 425.

Ladenburger, E. M. \& Plattner, H. 2011. Calcium release channels in Paramecium. Genomic expansion, differential positioning and partial transcriptional elimination. PLoS One, 6(11):e27111.

Ladenburger, E. M., Korn, I., Kasielke, N., Wassmer, T. \& Plattner, H. 2006. An Ins $(1,4,5) P_{3}$ receptor in Paramecium is associated with the osmoregulatory system. J. Cell Sci., 119:3705 3717.

Ladenburger, E. M., Sehring, I. M., Korn, I. \& Plattner, H. 2009. Novel types of $\mathrm{Ca}^{2+}$ release channels participate in the secre tory cycle of Paramecium cells. Mol. Cell. Biol., 29:3605 3622.

Lampert, T. J., Coleman, K. D. \& Hennessey, T. M. 2011. A knockout mutation of a constitutive GPCR in Tetrahymena decreases both G protein activity and chemoattraction. PLOS One, 6:e28022

Lange, S., Klauke, N. \& Plattner, H. 1995. Subplasmalemmal $\mathrm{Ca}^{2+}$ stores of probable relevance for exocytosis in Paramecium. Alveolar sacs share some but not all characteristics with sarco plasmic reticulum. Cell Calcium, 17:335 344.

Lange, S., Wissmann, J. D. \& Plattner, H. 1996. Caffeine inhibits $\mathrm{Ca}^{2+}$ uptake by subplasmalemmal calcium stores ('alveolar sacs') isolated from Paramecium cells. Biochim. Biophys. Acta, 1278:191 196.

Lee, H. C. 2012. Cyclic ADP ribose and nicotinic acid adenine dinucleotide phosphate (NAADP) as messengers for calcium mobilization. J. Biol. Chem., 287:31633 31640

Leondaritis, G. \& Galanopoulou, D. 2011. Emerging roles of phos phoinositide specific phospholipases $C$ in the ciliates Tetrahy mena and Paramecium. Commun. Integr. Biol., 4:576 578.

Leondaritis, G., Sarri, T., Dafnis, I., Efstathiou, A. \& Galanopoulou, D. 2011. Biochemical and genetic evidence for the presence of multiple phosphatidylinositol and phosphatidylinositol 4,5 bis phosphate specific phospholipases C in Tetrahymena. Eukaryot. Cell, 10:412 422.

Levitan, I. B. 1999. It is calmodulin after all! Mediator of the cal cium modulation of multiple ion channels. Neuron, 22:645 648

Linder, J. U., Engel, P., Reimer, A., Kruger, T., Plattner, H., Schultz, A. \& Schultz, J. E. 1999. Guanylyl cyclases with the topology of mammalian adenylyl cyclases and an $\mathrm{N}$ terminal P type ATPase like domain in Paramecium, Tetrahymena and Plasmodium. EMBO J., 18:4222 4232.

Luzio, J. P., Gray, S. R. \& Bright, N. A. 2010. Endosome lysosome fusion. Biochem. Soc. Trans., 38:1413 1416.

Machemer, H. 1988. Electrophysiology. In: Gortz, H. D. (ed.), Par amecium. Springer Verlag, Berlin, Heidelberg. p. 185215.

Machemer, H. \& Ogura, A. 1979. Ionic conductances of mem branes in ciliated and deciliated Paramecium. J. Physiol., 296:49 60
Machemer, H. \& Teunis, P. F. M. 1996. Sensory motor coupling and motor responses. In: Bradbury, P. C. \& Hausmann, K. (ed.), Ciliates. Cells and Organisms. Gustav Fischer Verlag, Stuttgart. p. 379402

Mackrill, J. J. 1999. Protein protein interactions in intracellular $\mathrm{Ca}^{2+}$ release channel function. Biochem. J., 337(345):361.

Marchesini, N., Ruiz, F. A., Vieira, M. \& Docampo, R. 2002. Acido calcisomes are functionally liked to the contractile vacuole of Dictyostelium discoidium. J. Biol. Chem., 277:8146 8153.

Marks, B. \& McMahon, H. T. 1998. Calcium triggers calcineurin dependent synaptic vesicle recycling in mammalian nerve termi nals. Curr. Biol., 8:740 749.

McCarron, J. G. \& Olson, M. L. 2008. A single luminally continu ous sarcoplasmic reticulum with apparently separate $\mathrm{Ca}^{2+}$ stores in smooth muscle. J. Biol. Chem., 283:7206 7218.

Mohamed, I., Klauke, N., Hentschel, J., Cohen, J. \& Plattner, H. 2002. Functional and fluorochrome analysis of an exocytotic mutant yields evidence of store operated $\mathrm{Ca}^{2+}$ influx in Parame cium. J. Membr. Biol., 187:1 14

Mohamed, I., Husser, M., Sehring, I., Hentschel, J., Hentschel, C. \& Plattner, H. 2003. Refilling of cortical calcium stores in Para mecium cells: in situ analysis in correlation with store operated calcium influx. Cell Calcium, 34:87 96.

Momayezi, M., Kersken, H., Gras, U., Vilmart Seuwen, J. \& Platt ner, H. 1986. Calmodulin in Paramecium tetraurelia: localization from the in vivo to the ultrastructural level. J. Histochem. Cyto chem., 34:1621 1638.

Momayezi, M., Lumpert, C. J., Kersken, H., Gras, U., Plattner, H., Krinks, M. H. \& Klee, C. B. 1987. Exocytosis induction in Paramecium tetraurelia cells by exogenous phosphoprotein phosphatase in vivo and in vitro: possible involvement of calci neurin in exocytotic membrane fusion. J. Cell Biol., 105:181 189.

Momayezi, M., Wloga, D., Kissmehl, R., Plattner, H., Jung, G., Klumpp, S. \& Schultz, J. E. 1996. Immunolocalization of protein phosphatase type 1 in Paramecium cells using antibodies against recombinant protein and peptides. J. Histochem. Cyto chem., 44:891905.

Momayezi, M., Kissmehl, R. \& Plattner, H. 2000. Quantitative im munogold localization of protein phosphatase 2B (calcineurin) in Paramecium cells. J. Histochem. Cytochem., 48:1269 1281.

Moniakis, J., Coukell, M. B. \& Janiec, A. 1999. Involvement of the $\mathrm{Ca}^{2+}$ ATPase PAT1 and the contractile vacuole in calcium regulation in Dictyostelium. J. Cell Sci., 112:405 414

Moreno, S. N. J. \& Docampo, R. 2003. Calcium regulation in pro tozoan parasites. Curr. Opin. Microbiol., 6:359 364.

Muller, S., Diederichs, K., Breed, J., Kissmehl, R., Hauser, K., Plattner, H. \& Welte, W. 2002. Crystal structure analysis of the exocytosis sensitive phosphoprotein, pp 63/parafusin (phospho glucomutase), from Paramecium reveals significant conforma tional variability. J. Mol. Biol., 315:141 153.

Narayanan, B., Islam, M. N., Bartelt, D. \& Ochs, R. S. 2003. A direct mass action mechanism explains capacitative calcium entry in Jurkat and skeletal L6 muscle cells. J. Biol. Chem., 278:44188 44196.

Neher, E. 2012. Introduction: regulated exocytosis. Cell Calcium, 52:196 198

Oertel, D., Schein, S. J. \& Kung, C. 1977. Separation of membrane currents using a Paramecium mutant. Nature, 268:120 124.

Oliveria, S. F., Dittmer, P. J., Youn, D. H., Dell'acqua, M. L. \& Sather, W. A. 2012. Localized calcineurin confers $\mathrm{Ca}^{2+}$ depen dent inactivation on neuronal $L$ type $\mathrm{Ca}^{2+}$ channels. J. Neuro sci., 32:15328 15337 
Palmgren, M. G. \& Nissen, P. 2011. P type ATPases. Annu. Rev. Biophys. Bioeng., 40:243 266.

Palty, R. \& Sekler, I. 2012. The mitochondrial $\mathrm{Na}^{+} / \mathrm{Ca}^{2+}$ exchanger. Cell Calcium, 52:9 15.

Patel, S. \& Docampo, R. 2009. In with the TRP channels: intracel lular functions for TRPM1 and TRPM2. Sci. Signal., 2:pe69.

Patel, S. \& Docampo, R. 2010. Acidic calcium stores open for business: expanding the potential for intracellular $\mathrm{Ca}^{2+}$ signal ing. Trends Cell Biol., 20:277 286.

Patel, S. \& Muallem, S. 2011. Acidic $\mathrm{Ca}^{2+}$ stores come to the fore. Cell Calcium, 50:109 112.

Plattner, H. 1987. Synchronous exocytosis in Paramecium cells. In: Sowers, A. E. (ed.), Cell Fusion. Plenum Press, New York. p. 6998.

Plattner, H. 2010. How to design a highly organized cell: an unex pectedly high number of widely diversified SNARE proteins positioned at strategic sites in the ciliate, Paramecium tetraur elia. Protist, 161:497 516

Plattner, H. \& Fuchs, S. 1975. X ray microanalysis of calcium bind ing sites in Paramecium with special reference to exocytosis. Histochemistry, 45:23 47

Plattner, H. \& Hentschel, J. 2006. Sub second cellular dynamics: Time resolved electron microscopy and functional correlation. Int. Rev. Cytol., 255:133 176.

Plattner, H. \& Klauke, N. 2001. Calcium in ciliated protozoa: sources, regulation, and calcium regulated cell functions. Int. Rev. Cytol., 201:115 208.

Plattner, H. \& Verkhratsky, A. 2013. Calcium signaling early in evolution all but primitive: $\operatorname{lns}_{3}$ and ryanodine receptor type $\mathrm{Ca}^{2+}$ release channels in lower eukaryotes. J. Cell Sci., 126:2141 2150

Plattner, H., Matt, H., Kersken, H., Haacke, B. \& Sturzl, R. 1984. Synchronous exocytosis in Paramecium cells. I. A novel approach. Exp. Cell Res., 151:6 13.

Plattner, H., Sturzl, R. \& Matt, H. 1985. Synchronous exocytosis in Paramecium cells. IV. Polyamino compounds as potent trig ger agents for repeatable trigger redocking cycles. Eur. J. Cell Biol., 36:32 37.

Plattner, H., Knoll, G. \& Pape, R. 1993. Synchronization of differ ent steps of the secretory cycle in Paramecium tetraurelia: Trichocyst exocytosis, exocytosis coupled endocytosis and intracellular transport. In: Plattner, H. (ed.), Membrane Traffic in Protozoa. JAI Press, Greenwich (CT); London. p. 123148.

Plattner, H., Braun, C. \& Hentschel, J. 1997a. Facilitation of mem brane fusion during exocytosis and exocytosis coupled endocy tosis and acceleration of "ghost" detachment in Paramecium by extracellular calcium. A quenched flow/freeze fracture analy sis. J. Membr. Biol., 158:197 208.

Plattner, H., Habermann, A., Kissmehl, R., Klauke, N., Majoul, I. \& Soling, H. D. 1997b. Differential distribution of calcium stores in Paramecium cells. Occurrence of a subplasmalemmal store with a calsequestrin like protein. Eur. J. Cell Biol., 72:297 306.

Plattner, H., Flotenmeyer, M., Kissmehl, R., Pavlovic, N., Hauser, K., Momayezi, M., Braun, N., Tack, J. \& Bachmann, L. 1999. Microdomain arrangement of the SERCA type $\mathrm{Ca}^{2+}$ pump $\left(\mathrm{Ca}^{2+}\right.$ ATPase $)$ in subplasmalemmal calcium stores of Parame cium cells. J. Histochem. Cytochem., 47:841 854.

Plattner, H. \& Kissmehl, R. 2005. Molecular aspects of rapid, reversible, $\mathrm{Ca} 2+$ dependent de phosphorylation of pp 63/parafu sin during stimulated exo endocytosis in Paramecium cells. Cell Calcium, 38:319 327

Plattner, H., Diehl, S., Husser, M. R. \& Hentschel, J. 2006. Sub second calcium coupling between outside medium and subplas malemmal stores during overstimulation/depolarisation induced ciliary beat reversal in Paramecium cells. Cell Calcium, 396:509 516

Plattner, H., Sehring, I. M., Schilde, C. \& Ladenburger, E. M. 2009. Pharmacology of ciliated protozoa drug (in)sensitivity and experi mental drug (ab)use. Int. Rev. Cell Mol. Biol., 273:163 218.

Plattner, H., Sehring, I. M., Mohamed, I. K., Miranda, K., De Sou za, W., Billington, R., Genazzani, A. \& Ladenburger, E. M. 2012. Calcium signaling in closely related protozoan groups (Alveola ta): non parasitic ciliates (Paramecium, Tetrahymena) vs. para sitic Apicomplexa (Plasmodium, Toxoplasma). Cell Calcium, 51:351 382.

Preston, R. R., Saimi, Y. \& Kung, C. 1992. Calcium current acti vated upon hyperpolarization of Paramecium tetraurelia. J. Gen. Physiol., 100:233 251.

Raffaello, A., De Stefani, D. \& Rizzuto, R. 2012. The mitochondrial $\mathrm{Ca}^{2+}$ uniporter. Cell Calcium, 52:16 21.

Ramachandran, S., Chakraborty, A., Xu, L., Mei, Y., Samsó, M., Dokholyan, N. V. \& Meissner, G. 2013. Structural determinants of skeletal muscle ryanodine receptor gating. J. Biol. Chem., 288:6154 6165 .

Reuter, A. T., Stuermer, C. A. O. \& Plattner, H. 2013. The microd omain forming stomatin family in the ciliated protozoan Parame cium tetraurelia: Identification, Iocalization and functional implications. Eukaryot. Microbiol., 12:529 544.

Ricklefs, R. E. \& Outlaw, D. C. 2010. A molecular clock for malaria parasites. Science, 329:226 229

Rizo, J., Chen, X. \& Arac, D. 2006. Unraveling the mechanisms of synaptotagmin and SNARE function in neurotransmitter release. Trends Cell Biol., 16:339 350.

Rohloff, P. \& Docampo, R. 2008. A contractile vacuole complex is involved in osmoregulation in Trypanosoma cruzi. Exp. Parasi stol., 118:17 24

Rusnak, F. \& Mertz, P. 2000. Calcineurin: form and function. Physiol. Rev., 80:1483 1521.

Schonemann, B., Bledowski, A., Sehring, I. M. \& Plattner, H. 2013. A set of SNARE proteins in the contractile vacuole com plex of Paramecium regulates cellular calcium tolerance and also contributes to organelle biogenesis. Cell Calcium, 53:204 216.

Schultz, J. E. \& Klumpp, S. 1993. Cyclic nucleotides and calcium signaling in Paramecium. Adv. Second Messenger Phosphopro tein Res., 27:25 46.

Sehring, I. M. \& Plattner, H. 2004. $\mathrm{Ca}^{2+}$ oscillations mediated by exogenous GTP in Paramecium cells: assessment of possible $\mathrm{Ca}^{2+}$ sources. Cell Calcium, 36:409 420.

Sehring, I. M., Klotz, C., Beisson, J. \& Plattner, H. 2009. Rapid downregulation of the $\mathrm{Ca}^{2+}$ signal after exocytosis stimu lation in Paramecium cells: essential role of a centrin rich filamentous cortical network, the infraciliary lattice. Cell Calcium, 45:89 97.

Shenolikar, S. 1994. Protein serine/threonine phosphatases new avenues for cell regulation. Annu. Rev. Cell Biol., 10:55 86.

Solovyova, N. \& Verkhratsky, A. 2003. Neuronal endoplasmic reticulum acts as a single functional $\mathrm{Ca}^{2+}$ store shared by ry anodine and inositol 1,4,5 trisphosphate receptors as revealed by intra ER $\left[\mathrm{Ca}^{2+}\right]$ recordings in single rat sensory neurones. Pflugers Arch., 446:447 454.

Stelly, N., Mauger, J. P., Claret, M. \& Adoutte, A. 1991. Cortical alveoli of Paramecium: a vast submembranous calcium storage compartment. J. Cell Biol., 113:103 112.

Stock, C., Grønlien, H. K. \& Allen, R. D. 2002. The ionic composi tion of the contractile vacuole fluid of Paramecium mirrors ion transport across the plasma membrane. Eur. J. Cell Biol., 81:505 515. 
Sugita, S., Shin, O. H., Han, W., Lao, Y. \& Sudhof, T. C. 2002. Synaptotagmins form a hierarchy of exocytotic $\mathrm{Ca}^{2+}$ sensors with distinct $\mathrm{Ca}^{2+}$ affinities. EMBO J., 21:270 280.

Sussmann, M. R., Hrabak, E. M. \& Satterlee, J. S. 1996. Calmod ulin domain protein kinase. In: Celio, M. R., Pauls, T. L. \& Schwaller, B. (ed.), Calcium Binding Proteins. Oxford University Press, Oxford, GB. p. 4648.

Tarasov, A. I., Griffiths, E. J. \& Rutter, G. A. 2012. Regulation of ATP production by mitochondrial $\mathrm{Ca}^{2+}$. Cell Calcium, 52:28 35.

Thakur, P., Dadsetan, S. \& Fomina, A. F. 2012. Bidirectional coupling between ryanodine receptors and $\mathrm{Ca}^{2+}$ release activated $\mathrm{Ca}^{2+}$ (CRAC) channel machinery sustains store operated $\mathrm{Ca}^{2+}$ entry in human T lymphocytes. J. Biol. Chem., 287:37233 37244.

Vetter, D., Kissmehl, R., Treptau, T., Hauser, K., Kellermann, J. \& Plattner, H. 2003. Molecular identification of a calcium inhibited catalytic subunit of casein kinase type 2 from Paramecium te traurelia. Eukaryot. Cell, 2:1220 1233.

Vilmart Seuwen, J., Kersken, H., Sturzl, R. \& Plattner, H. 1986. ATP keeps exocytosis sites in a primed state but is not required for membrane fusion: an analysis with Paramecium cells in vivo and in vitro. J. Cell Biol., 103:1279 1288

Wagenknecht, T. \& Radermacher, M. 1997. Ryanodine receptors: structure and macromolecular interactions. Curr. Opin. Struct. Biol., 7:258 265.

Wang, X., Zhang, X., Dong, X. P., Samie, M., Li, X., Cheng, X., Goschka, A., Shen, D., Zhou, Y., Harlow, J., Zhu, M. X., Clap ham, D. E., Ren, D. \& Xu, H. 2012. TPC proteins are phospho inositide activated sodium selective ion channels in endosomes and lysosomes. Cell, 151:372 383.

Wassenberg, J. J., Clark, K. D. \& Nelson, D. L. 1997. Effect of SERCA pump inhibitors on chemoresponses in Paramecium. J. Eukaryot. Microbiol., 44:574 581.

Wassmer, T., Froissard, M., Plattner, H., Kissmehl, R. \& Cohen, J. 2005. The vacuolar proton ATPase plays a major role in sev eral membrane bounded organelles in Paramecium. J. Cell Sci., 118:2813 2825.

Wassmer, T., Kissmehl, R., Cohen, J. \& Plattner, H. 2006. Seven teen a subunit isoforms of Paramecium V ATPase provide high specialization in localization and function. Mol. Biol. Cell, 17:917 930.
Wassmer, T., Sehring, I. M., Kissmehl, R. \& Plattner, H. 2009. The V ATPase in Paramecium: functional specialization by multi ple gene isoforms. Pflugers Arch., 457:599 607.

Williams, A. J., West, D. J. \& Sitsapesan, R. 2001. Light at the end of the $\mathrm{Ca}^{2+}$ release channel tunnel: structures and mecha nisms involved in ion translocation in ryanodine receptor chan nels. Q. Rev. Biophys., 34:61 104.

Wright, M. V. \& van Houten, J. L. 1990. Characterization of a putative $\mathrm{Ca}^{2+}$ transporting $\mathrm{Ca}^{2+}$ ATPase in the pellicles of Para mecium tetraurelia. Biochim. Biophys. Acta, 1029:241 251.

Wu, M. M., Luik, R. M. \& Lewis, R. S. 2007. Some assembly required: constructing the elementary units of store operated $\mathrm{Ca}^{2+}$ entry. Cell Calcium, 42:163 172.

Xiao, R. P., Valdivia, H. H., Bogdanov, K., Valdivia, C., Lakatta, E. G. \& Cheng, H. 1997. The immunophilin FK506 binding protein modulates $\mathrm{Ca}^{2+}$ release channel closure in rat heart. J. Physiol., 500:343 354

Xiong, Z., Lu, W. \& MacDonald, J. F. 1997. Extracellular calcium sensed by a novel cation channel in hippocampal neurons. Proc. Natl Acad. Sci. U S A, 94:7012 7017.

Yang, W. Q., Braun, C., Plattner, H., Purvee, J. \& Van Houten, J. L. 1997. Cyclic nucleotides in glutamate chemosensory signal transduction of Paramecium. J. Cell Sci., 110:2567 2572.

Yano, J., Rajendran, A., Valentine, M. S., Saha, M., Ballif, B. A. \& Van Houten, J. L. 2013. Proteomic analysis of the cilia mem brane of Paramecium tetraurelia. J. Proteom., 78:113 122.

Yoo, S. H., Huh, Y. H. \& Hur, Y. S. 2010. Inositol 1,4,5 trisphos phate receptor in chromaffin secretory granules and its relation to chromogranins. Cell. Mol. Neurobiol., 30:1155 1161.

Zalk, R., Lehnart, S. E. \& Marks, A. R. 2007. Modulation of the ry anodine receptor and intracellular calcium. Annu. Rev. Bio chem., 76:367 385.

Zieseniss, E. \& Plattner, H. 1985. Synchronous exocytosis in Para mecium cells involves very rapid $(<1 \mathrm{~s})$, reversible dephosphor ylation of a $65 \mathrm{kD}$ phosphoprotein in exocytosis competent strains. J. Cell Biol., 101:2028 2035.

Zucchi, R. \& Ronca Testoni, S. 1997. The sarcoplasmic reticulum $\mathrm{Ca}^{2+}$ channel/ryanodine receptor: modulation by endogenous effectors, drugs and disease states. Pharmacol. Rev., 49:1 51. 